IZA DP No. 7456

Flight of the H-1B: Inter-Firm Mobility and Return Migration Patterns for Skilled Guest Workers

\author{
Briggs Depew \\ Peter Norlander \\ Todd A. Sørensen
}

June 2013 


\title{
Flight of the H-1B: Inter-Firm Mobility and Return Migration Patterns for Skilled Guest Workers
}

\author{
Briggs Depew \\ Louisiana State University \\ Peter Norlander \\ UCLA Anderson School of Management \\ Todd A. Sørensen \\ University of California, Riverside \\ and IZA
}

Discussion Paper No. 7456

June 2013

IZA
P.O. Box 7240
53072 Bonn
Germany

Phone: +49-228-3894-0

Fax: +49-228-3894-180

E-mail: iza@iza.org

\begin{abstract}
Any opinions expressed here are those of the author(s) and not those of IZA. Research published in this series may include views on policy, but the institute itself takes no institutional policy positions. The IZA research network is committed to the IZA Guiding Principles of Research Integrity.

The Institute for the Study of Labor (IZA) in Bonn is a local and virtual international research center and a place of communication between science, politics and business. IZA is an independent nonprofit organization supported by Deutsche Post Foundation. The center is associated with the University of Bonn and offers a stimulating research environment through its international network, workshops and conferences, data service, project support, research visits and doctoral program. IZA engages in (i) original and internationally competitive research in all fields of labor economics, (ii) development of policy concepts, and (iii) dissemination of research results and concepts to the interested public.
\end{abstract}

IZA Discussion Papers often represent preliminary work and are circulated to encourage discussion. Citation of such a paper should account for its provisional character. A revised version may be available directly from the author. 


\section{ABSTRACT \\ Flight of the H-1B: \\ Inter-Firm Mobility and Return Migration Patterns for Skilled Guest Workers}

Critics of the H-1B program for high-skilled workers argue that the program restricts immigrant job mobility and lacks a vehicle for adjusting the number of visas during a recession. We study the job mobility of highly-skilled Indian IT guest workers and provide new evidence on their inter-firm mobility and return migration patterns. We use a unique multi-year firm level dataset to show that, outside of the Great Recession, these workers are mobile and that lower paid guest workers are more likely than higher paid guest workers to separate to another firm in the U.S. We also analyze return migration decisions and find that low wage workers repatriate more than high wage workers, and that this relationship intensified during the Great Recession. This partially mitigates concerns that guest worker visa programs do not adjust to fluctuations in the macro economy. Following this finding, we show that the employment to population ratio (EPOP) for highly-skilled male workers has fallen at a much steeper rate since 2008 than is typically recognized, once we account for the phenomenon of discouraged immigrants.

JEL Classification: F22, J42, E32

Keywords: $\quad$ skilled migration, labor market frictions, business cycles

Corresponding author:

Todd A. Sørensen

Department of Economics

4128 Sproul Hall

University of California, Riverside

Riverside, CA 92521-0427

USA

E-mail: todd.sorensen@ucr.edu

\footnotetext{
*We would like to thank Randy Akee, Leah Boustan, Gordon Dahl, Dave Fairris, Bill Lincoln, Mindy Marks, Chad Sparber, Doug Webber, and Tiemen Woutersen for their helpful comments. In addition, we appreciate the feedback received at UCLA, UT-Dallas and UT-Austin.
} 


\section{Introduction}

One of the main conduits for skilled migration, the H-1B visa program, admits up to 85,000 new skilled immigrant workers annually to the U.S. ${ }^{1}$ Comprehensive immigration reform proposals would increase the number of $\mathrm{H}-1 \mathrm{~B}$ visas, make it easier to transfer visas between employers, and further penalize firms that are heavy visa-users (MacDonald, Lopez, Decker and Valerio 2013). Proponents of an expanded program argue that higher levels of skilled immigration will lead to higher growth rates through more innovation, consistent with the work of Kerr and Lincoln (2010) and Hunt and Gauthier-Loiselle (2010) while opponents argue that there are negative consequences of high-skill immigration on native workers' labor market outcomes, consistent with the work of Borjas (2009) and Borjas and Doran (2012). Our analysis addresses existing concerns about the institutional features of the H-1B visa program itself, in particular concerns raised by Hira (2010) and others that: 1) "guest workers [on the visa] can find themselves in working conditions akin to indentured servitude" (Dorning and Fanning 2012), 2) firms pay workers on these visas below-market wages, and 3) the program has no labor market test to ensure that immigrants do not crowd out citizens during periods of heightened unemployment. $^{2}$ In this paper, we provide rigorous evidence to aid in the assessment of these three concerns.

We investigate the inter-firm mobility and return migration patterns of guest workers with a dataset that includes a large number of $\mathrm{H}-1 \mathrm{~B}$ visa holders. Accordingly, we present new evidence using unique job mobility data for over 70,000 Indian workers on temporary visas who worked at six large Indian information technology firms in the U.S. from 2003-2011. The use of firm level data allows us to study this topic for a sizable and particularly important portion of the H-1B program population. Our results cast doubt on the claim that these workers faced severe mobility restrictions outside of the Great Recession. They reveal that during periods of full employment, inter-firm mobility of these workers is comparable to other estimates in the literature obtained from presumably more mobile workers in other labor markets, suggesting that competitive market forces provide some check against firms dramatically underpaying these workers. We also find that these workers return to India at significantly higher rates during weak labor markets, at least partially mitigating concerns of excess supply of immigrant workers during a recession.

The present paper stands at the intersection of research on skilled immigration and labor market frictions. Typically, if firms take advantage of workers, then workers' primary recourse should be to freely quit their jobs and find better employers. However, guest worker programs impose frictions that inhibit inter-firm mobility. For example, the explicit cost of transferring an H-1B visa between employers ranges between $\$ 2000$ and $\$ 5225$, according to the current fees found on

\footnotetext{
${ }^{1}$ See http://www.uscis.gov for detailed statistics on visas granted.

${ }^{2}$ Further information suggesting that workers on these visas may be vulnerable to exploitation includes the following EPI report Hira (2010), AFL-CIO report (Dorning and Fanning 2012), and research by Matloff (2002) and Chakravartty (2006).
} 
the USCIS website. ${ }^{3}$ Job mobility in a market with this type of friction has yet to be empirically addressed in the literature, but intuition would strongly suggest that workers laboring in such an institutional setting would be less mobile (for a discussion of institutions and labor markets, see Blau and Kahn (1999)). In the monopsony framework of Manning (2003), the degree of inter-firm mobility of workers directly affects a firm's ability to pay workers less than their marginal product. ${ }^{4}$ This suggests a labor market that is ripe for exploitation.

During periods of full employment, our analysis suggests that the degree of inter-firm mobility as measured by the elasticity of quits with respect to wages is similar to other studies of mobility for workers not facing these government imposed frictions. We find that the elasticity does drop significantly with the start of the Great Recession, consistent with Depew and Sorensen (2012). If anything, our results for $\mathrm{H}-1 \mathrm{~B}$ visa holders are likely to be biased downward (towards higher levels of exploitation) for two reasons: in addition to the standard omitted variable bias, our dataset includes an unknown number of workers on L-1 visas who are completely immobile (both are discussed in detail later).

Current reforms proposed in Congress would adjust the number of visas to business cycle fluctuations in order to ensure that the program does not harm citizens during especially high periods of unemployment. We present estimates of rates of return migration to India, and find that lower paid workers are more likely to return than higher paid workers, consistent with earlier research (Abramitzky, Boustan and Eriksson 2012). We find for the first time that the responsiveness of return migration with respect to wage generally increases during economic downturns as does the overall probability of return migration. This pattern of return migration should partially alleviate some concerns of opponents of the program. Additionally, we note the importance of return migration in measuring the general health of labor markets. Specifically, the employment to population ratio for prime-aged male workers with a college degree in 2011 would have been even worse in a counterfactual scenario in which migration patterns did not fluctuate during the Great Recession. We find that recalculating the ratio by adding back in people we term discouraged immigrants reveals nearly twice as large a decline in the employment to population (EPOP) ratio. Our findings suggest that return migration acts as an automatic adjuster of immigration levels during periods of heightened unemployment, and that current institutional features of the $\mathrm{H}-1 \mathrm{~B}$ program do not lead to egregious exploitation.

\footnotetext{
${ }^{3}$ See http://www.uscis.gov for details on the level of these fees.

${ }^{4} \mathrm{~A}$ small but growing body of recent work has found evidence across a variety of settings that inter-firm mobility with respect to wages is relatively low when compared to the assumption of perfect competition (most estimates of quit elasticities range between -.5 and -2.5 ), suggesting that some firm wage setting power may exist. Examples include Boal (1995), Ransom and Oaxaca (2010), Hirsch, Shank and Schnabel (2006), Hirsch (2007), Hotchkiss and Quispe-Agnoli (2009), Ransom and Sims (2010), Hirsch, Shank and Schnabel (2010), Falch (2010), Ransom and Lambson (2011), Falch (2011), Dube, Lester and Reich (2011), Depew and Sorensen (2012) and Webber (2011).
} 


\section{Background on Skilled Guest Worker Visas}

The Immigration Act of 1990 created the H-1B and L-1 visa categories. The H-1B visa program is intended to enable organizations to bring workers into the U.S. in certain skilled occupations experiencing labor shortages, and is the largest visa source of skilled immigrants. As noted by Kerr, Kerr and Lincoln (2013), skilled immigration through the $\mathrm{H}-1 \mathrm{~B}$ visa program is of great importance to the U.S. workforce given demographic trends and technical needs. The L-1 visa is meant for multinational firms that need to transfer overseas workers to their U.S. operations. Both are considered "non-immigrant" visas, meaning that guest workers on these visas are expected to return to their home country when their visa expires. The visas do have a "dual intent," however, and it is possible to apply for permanent residency while on a $\mathrm{H}-1 \mathrm{~B}$ or $\mathrm{L}-1$ visa. Individuals who receive $\mathrm{H}-1 \mathrm{~B}$ visas are required to be of "distinguished merit or ability" while holders of L-1 visas are expected to possess "specialized knowledge." Both the H-1B and L-1 visas are issued to individuals for initial periods of 3 years and may be renewed once for a total of 6 years, after which the temporary worker must either return home or apply for permanent residency. ${ }^{5}$

Tight labor markets, the "Dot-Com" boom and Y2K issues of the late 1990s created a perception of labor shortages in the IT Industry. Even today, despite elevated unemployment rates, companies continue to report severe difficulty finding skilled workers in the Science, Technology, Engineering and Mathematics (STEM) occupations. One response to these shortages has been calls for more immigration of skilled workers. Skilled immigration reform proposals center around the H-1B and L-1 visas that are the most frequently used by computer professionals: in fiscal year 2010, $47 \%$ of H-1B recipients were in computer-related occupations (Wasem 2012).

In its last major revision of the $\mathrm{H}-1 \mathrm{~B}$ visa program, The American Competitiveness and Worker Investment Act for the 21st Century of 2000 (AC21), Congress addressed some concerns about the "portability" of the H-1B visa and enacted reforms aimed at preventing worker exploitation. Prior to AC21, H-1B workers had been able to switch employers only after the approval of a new petition, which could take in excess of six months to obtain. With the AC21 revision, workers who were already on an $\mathrm{H}-1 \mathrm{~B}$ visa could now switch employers immediately upon the initiation of a sponsorship petition by their new employer. As the Congressional Record indicates, Congress felt that a competitive and properly functioning labor market was critical in order to insure that $\mathrm{H}-1 \mathrm{~B}$ workers were not exploited. As the legislative committee report declared, "the market would not tolerate exploitation, especially given the fierce competition for skilled workers. An H-1B employee who

\footnotetext{
${ }^{5}$ An annual cap of 65,000 was initially placed on the number of $\mathrm{H}-1 \mathrm{~B}$ visas available. The American Competitiveness and Workforce Improvement Act of 1998 increased the $\mathrm{H}-1 \mathrm{~B}$ visa cap to 115,000 for 1999 and 107,500 for 2000. The American Competitiveness and Worker Investment Act for the 21st Century of 2000 (AC21) increased the cap to 195,000 through 2003, after which the number of visas reverted to 65,000. Additional changes allowed another 20,000 recipients of post graduate degrees obtained in the U.S. to receive this visa.
} 
is not being treated fairly can easily be petitioned by another employer and switch to work for that employer" (Hatch 2000).

Despite these reforms, there is reason to believe that frictions in this labor market are still being created by government regulations. A skilled worker who meets the eligibility criteria for a $\mathrm{H}-1 \mathrm{~B}$ or L-1 visa cannot find employment in the U.S. without also finding an employer willing to undergo a time-consuming visa application and sponsorship process. To transfer a worker who already holds an H-1B visa from their current employer, the hiring employer must initiate a visa application in a regulatory system that requires application and legal fees. ${ }^{6}$ In addition to $\$ 2,000$ of administrative costs, the fees currently listed on the USCIS website are $\$ 2,000$ for all employers, an additional $\$ 2,000$ for large employers of $\mathrm{H}-1 \mathrm{~B}$ visas, and an additional $\$ 1,225$ for expedited processing. Would-be employers must also provide evidence regarding the non-displacement and notification of incumbent workers. These regulations generate significant paperwork for the employer (the forms required have an estimated paperwork burden of 3 hours and 45 minutes), and should theoretically limit the number of employers willing to hire $\mathrm{H}-1 \mathrm{~B}$ workers, decreasing outside options for these workers. Meanwhile, regulations for workers on L-1 visas explicitly prohibit them from switching jobs.

Several case studies have uncovered worker testimony regarding the implications of employer unwillingness to sponsor H-1B workers. Compared to having a green card (which allows workers to obtain another job without employer sponsorship), H-1B workers reported feeling "bound" and "tied down" to their employers (Banerjee 2006, Banerjee 2009). Banerjee also reported that workers employed by Indian IT contractors found it difficult to obtain work directly from American firms, which preferred to maintain flexibility by outsourcing labor to Indian IT and other subcontractor firms, and that workers felt that their inability to switch employers meant that they weren't treated as equal members of the labor market, leading to lower wages, longer working hours, and decreased opportunities. As a worker in another study put it, "It's not as free of a market. Maybe not deliberately, but companies take them (H-1B workers) for granted...The pay is lower, $\$ 20,000$ at my level, because we are less mobile. They take advantage of the situation" (Chakravartty 2006). Thus, this immobility may lead to firm market power over workers. Market power generally decreases economic efficiency of the labor market and therefore the degree of immobility plays a role in the performance of the economy. The actual degree of immobility of these workers is an important empirical question which our unique dataset will allow us to rigorously assess.

The most convincing evidence of a negative effect of costly job mobility on wages comes from studies of what happens to workers on temporary visas after

\footnotetext{
${ }^{6} \mathrm{~A}$ brief history of the fees includes a $\$ 1,000$ fee on large employers that sunset on October 1, 2003; but after December 8, 2004, this fee was restored and increased to $\$ 1,500$; after March 8, 2005, firms had to pay an additional $\$ 500$ fraud prevention fee; from February 17, 2009 to February 17, 2011, the Employ American Workers Act imposed additional restrictions on banks receiving bailout funds hiring workers on $\mathrm{H}-1 \mathrm{~B}$ visas, and after August 14, 2011, an additional $\$ 2,000$ fee was imposed on each petition for a H-1B worker for certain employers. This information is available at the USCIS website.
} 
they obtain a green card. Two studies using data from the New Immigrant Survey show that temporary workers receive a $20-25 \%$ wage boost once they receive a green card (Mukhopadhyay and Oxborrow 2012, Kandilov 2007). Another study that examines the difference between citizens, green card holders and temporary workers finds that IT workers with a green card earn only $6.1 \%$ more than IT workers without a green card (Mithas and Lucas 2010).

The Immigration and Nationality Act requires employers of $\mathrm{H}-1 \mathrm{~B}$ visa workers to pay these workers the prevailing wage and prohibits discrimination against these workers with respect to pay and benefits. Prevailing wages are required to be the average wage for workers in similar jobs in the area of employment, and firms may use salary surveys to set these minimum wages. Studies using prevailing wage documentation filed by firms find that H-1B workers earn less (Miano 2005), and a review of studies released by think tanks finds that $\mathrm{H}-1 \mathrm{~B}$ workers are paid 15$33 \%$ less than comparable workers (Matloff 2006). These studies, as Mithas and Lucas (2010) note, suffer various flaws, stemming from their inability to account for experience and education and the unreliability of their data. ${ }^{7}$ Mithas and Lucas (2010) find that workers on $\mathrm{H}-1 \mathrm{~B}$ visas earn more than citizens after conditioning on age, education, and experience. But weaknesses in Mithas and Lucas' (2010) study warrant further examination. First, their data comes from a non-random internet survey of 50,000 IT professionals by InformationWeek magazine, raising questions about the representativeness of the sample. Second, the data does not contain information on detailed occupation or tasks performed by the worker. Thus it is hard to directly compare immigrant and citizens wages in their data.

Using higher quality administrative data, Lofstrom and Hayes (2011) finds that the earnings gap between H-1B workers and naturalized citizens was $13.6 \%$ in 2009 while the gap between H-1B workers and all U.S. citizens was 3.1 percent. Again, an empirical assessment of how much inter-firm mobility workers may exhibit (and the likely corresponding firm wage setting power) will allow us to provide more evidence on the likelihood that these workers are severely underpaid.

\section{Data and Empirical Strategy}

\subsection{Data}

The companies in our dataset are large Indian information technology companies and are members of an industry (the Indian IT industry) that is a large employer of $\mathrm{H}-1 \mathrm{~B}$ and L-1 workers. Companies in this industry are the largest users of

\footnotetext{
${ }^{7}$ Employers applying for H-1B visas must file a Labor Condition Application (LCA) with the Labor Department declaring the number of foreign workers, workers in each occupation, and wages at a particular work establishment. A frequent data source used by firms when filing LCAs is the Occupational Employment Statistics data provided by the BLS, which provides wage data by occupation and geographical region. One of the key problems with using this data, however, is that LCAs are attached to work locations and not to workers and thus aren't necessarily a reflection of actual wages paid.
} 
these visa programs; these "offshore outsourcing" companies contract with major corporations in the U.S. and elsewhere to act as intermediaries in the supply of IT services (Hira 2010). Our dataset includes records from 6 Indian IT firms and 72,575 employees for the years 2003-2011. Given estimates that only 270,000 H1B workers are in the country at a given time, our sample is a sizable portion of the stock of H-1B workers (Lowell 2000). As is typical in the Indian IT industry, the employees are a mix of H-1B, L-1, and U.S. citizens and permanent residents, although the visa holders are the vast majority of these workers (Hira 2010). We do not capture the individual's visa status. This means we have an unknown number of L-1 holders in our dataset, as well as a small number of permanent residents and citizens. Hira (2010) cites three reasons why these firms do not hire U.S. workers: to facilitate knowledge transfer to India, to have an inexpensive labor source in the U.S., and to train workers who will return to India and continue to support operations remotely. Because L-1 workers cannot change employers we will not observe any quits to competing firms for them. To sharpen the focus on workers holding visas, we eliminate from our dataset workers who earn less than $\$ 30,000$ and more than $\$ 130,000$, creating a window that should capture most of those in the dataset who are on visas, rather than high paid American executives at the company, or low paid American staff, such as clerical and custodial workers.

Information in the dataset includes the start date of employment at the firm in question in the U.S. and an exit date. The exit date takes two forms: it either notes the date on which a worker returned to India, or notes the date on which a worker otherwise separates from employment (legally, these workers would have to have gained employment at another firm in the U.S. in order to remain in the country). ${ }^{8}$ Because the workers would have to quickly find new employment, we believe that the vast majority of separations (other than returns to India) observed are voluntary separations to employment at other U.S. firms. We therefore refer to these exits as "quits." In contrast, some returns to India may involve the worker's choice to return migrate for personal reasons, while some others clearly are involuntary separations: when work is finished on a software development project or training is complete, an employee leaves the U.S., and therefore a return to India is observed.

Other observable characteristics in the data include the base annual salary as well as the age, gender, and the state in which the employee worked. Each of these variables are observed on the last date available (i.e. the data are not time-varying). We do not capture hours worked.

We now turn to the summary statistics of our dataset. In Table 1, we present the mean and standard deviations of key variables in our sample. The mean salary in our dataset is $\$ 72,182$ with a standard deviation of $\$ 15,416$. Note that the range of salaries in our sample is restricted to $\$ 30,000$ - $\$ 130,000$ for reasons discussed earlier in this section. Twenty-two percent of our observations quit during our entire period of study, and twenty-nine percent returned to India during this time. Our summary statistics also show that married individuals are a majority of our

${ }^{8}$ A worker who did not obtain employment would be "out of status." See http://www.uscis.gov/USCIS/Resources/C2en.pdf for details. 
observations, and that our sample is overwhelmingly young and male. ${ }^{9}$ We also report an average unemployment rate of $7.79 \%$ faced by workers over the entire time period in our sample.

Figure 1 shows the density of quits to another firm and returns to India for the entire sample by days of tenure. The density increases for approximately the first year of employment, and then declines for the remainder of the period. This suggests that any analysis which assumes a monotonic relationship between the hazard of separating and time will be incorrectly specified. In the figure, vertical lines are placed at three years and six years of tenure. We do not observe spikes in returns around three or six years, which is when visa authorizations end. This suggests that the workers' separations and returns are driven by decisions not directly related to visa expiration dates.

Figure 2 shows changes in quit and return rates over time. We see the return rate spike in 2008 , which would suggest that fears that guest workers adversely impact citizens, especially during economic downturns, are at least partially mitigated by their increased propensity to return migrate to their home country during bad labor markets. In contrast, the quit rate decreases during hard economic times, suggesting that inter-firm job mobility may be hampered during recessions, and that these workers have a smaller quit elasticity with respect to wage in times of higher unemployment. The estimated cyclicality of these elasticities are presented in the results section.

\subsection{Empirical Strategy}

Here we describe our empirical strategy for estimating the elasticity of separations with respect to earnings for Indian IT workers who are in the U.S. on temporary visas. We choose to study separations to other firms and returns to India by estimating "quit elasticities" and "return elasticities," respectively. We begin with a discussion of our econometric model. This is followed by a description of how the model identifies the key empirical parameters of our study. Finally, we discuss threats to identification.

We estimate the two elasticities discussed above using duration analysis. The use of a duration model is a logical fit for modeling the length of an employment spell, as it allows us to exploit the time dependence of duration data in order to estimate the effects of various regressors on the length of an employment spell.

Most recent work studying the relationship between compensation and employee separation has used linear, probit, or logit models. A small number of studies have used single risk duration models: Webber (2011) estimates the elasticity of separation for US workers, Hirsch et al. (2010) estimates the elasticity of separation by gender and Hirsch and Jahn (2012) estimates the elasticity of separation by nativity. Other notable papers studying different aspects of job mobility have also

\footnotetext{
${ }^{9}$ Lofstrom's sample of all H-1B visa holders from 2009 had a mean age of 30.6 in Information Technology, and annual earnings averaging $\$ 76,698$. This is comparable to our sample's average age of 29.5 and earnings of $\$ 72,182$.
} 
used hazard models (Booth, Francesconi and Garcia-Serrano 1999, Farber 1994).

Our preferred duration model is the competing risk hazard model (Fine and Gray 1999). To our knowledge, we are the first to apply a competing risk model in this setting. Because individuals exit the firm through both separation to another firm as well as through returns to India, a competing risk model is more appropriate than a single risk hazard model, such as the commonly used Cox proportional hazard model. The competing risk hazard model that we employ here is similar to the Cox model in that it also non-parametrically estimates the baseline hazard. The fact that the model makes no assumptions about the shape of the baseline hazard is advantageous because Figure 1 shows that a non-monotonic relationship between the hazard of separation and time at the firm exists in our data.

Below, we show the hazard of separation (either quit or return) given by the competing risk hazard function. The instantaneous hazard of separation is

$$
\lambda_{i, j}(t)=\lambda_{0, j}(t) \exp \left\{\beta^{j} w_{i}+\delta^{j} X_{i}+\gamma^{j} V_{i t}\right\}
$$

for each individual $i$ and risk $j$ ( $j=$ quit,return). $t$ is the duration of employment at the firm. $\quad \lambda_{0, j}(t)$ is the non-parametric baseline hazard that is constant for all individuals, but varies over time and between risks. The main regressor of interest, $w_{i}=\ln \left(\right.$ salary $\left._{i}\right)$, is the $\log$ annual final salary of the worker. $X_{i}$ is a vector of observable characteristics that affect the duration of employment and are constant over time. ${ }^{10}$ Included in $X_{i}$ are sex, marital status, start age, start age squared, firm specific indicators and year and month indicators. $V_{i t}$ is a vector of observable characteristics that vary over time for each individual in the study. Included in $V_{i t}$ is the level and square of the state unemployment rate that individual $i$ faces at duration time $t$.

To obtain the quit elasticity, we estimate equation 1 specifying the main risk as employment ending by the worker exiting the firm to employment at another firm in the U.S. Through the hazard model we count as right censored the observations of workers who remained in employment throughout our study, and we specify returns to India as a competing risk. For this specified treatment of the data, $\beta$ in equation 1 represents the quit elasticity. A simple wage posting search model suggests that $\beta$ is less than zero because workers who are receiving a lower wage, holding all else constant, are more likely to receive an outside wage offer that dominates their current wage (see Appendix). If Indian guest workers are immobile, as others have suggested, then $\beta$ should be zero. A quit elasticity of zero suggests that wages play no role in the mobility of these workers and therefore firms are able to pay these workers their reservation salary. ${ }^{11}$ To our knowledge, the estimation of equation

\footnotetext{
${ }^{10}$ As discussed earlier, although some of these characteristics are likely to change over time, they are constant in the data.

${ }^{11}$ By law, $\mathrm{H}-1 \mathrm{~B}$ workers are required to receive the prevailing wage and this limits the ability of firms to markdown wages beyond a certain point. However, a profit maximizing firm may be able to hire workers who are more productive than natives in unobserved dimensions and then pay them the prevailing wage, which in effect would be a form of discrimination.
} 
1 will provide the first empirical evidence of the role of wages in the separation decisions of H-1B workers. In addition, we are the first to estimate quit elasticities using an estimator that accounts for the competing risk of involuntary separations.

We similarly estimate the return elasticity by estimating the effect of log salary on the likelihood that an employment spell ends through a return to India. We treat all other quits from the firm as competing risks in this analysis. Using this specification of the separation decision, $\beta$ in equation 1 is the return elasticity. Workers may return to India after being fired or laid off, or after voluntarily quitting. It is unclear if firms are more likely to terminate the employment of higher or lower wage workers. However, just as lower wage workers are more likely to find better outside options within the U.S., we also believe that they may be more likely to return to India as well. Thus we expect this estimate of $\beta$ to be negative as well.

To further shed light on the workings of the H-1B Indian IT labor market in the U.S., we estimate how the elasticities of separation change over the business cycle. We do this by using variation in state level unemployment rates to proxy for tightness of labor markets. Depew and Sorensen (2012) show that the Burdett-Mortensen search model in the framework of Manning (2003) implies that the elasticity of quits is likely to be more elastic during economic expansions than recessions. Using employee records from two manufacturing firms from the interwar period, they were able to confirm this finding with empirical evidence. However, they do so using only variation over time between expansions and recession, while here we are able to exploit both across time and across state variation in the unemployment rate.

Understanding how the elasticity of quits varies over the business cycle is of particular interest because it would demonstrate whether or not the labor market for H-1B Indian IT workers is similar to other labor markets that become more competitive during expansions as inter-firm mobility increases and less competitive during recessions as this mobility slows down. Additionally, understanding the cyclicality of the elasticity of returns informs us as to how the selection of these migrants and the level of return migration may change over the business cycle. Understanding this process is of importance to opponents of the program who fear that the presence of these workers during economic downturns may harm natives.

Our work is not unique in studying wages and mobility over the business cycle; this question has been examined in previous studies such as Solon, Whately and Stevens (1997) and Devereux and Hart (2006). However, neither of these previous works estimates elasticities of separation nor do they study the mobility behavior of immigrants. We study changes in the elasticity of separation over the business cycle by adding interactions of log salary $\left(w_{i}\right)$ and the unemployment rate in the hazard function in equation 1 . We choose to interact both the level and square of the unemployment rate with log salary because it is likely that there exists a non-linear relationship between the elasticity of separation and the unemployment rate. Therefore, the competing risk model of interest takes the form

$$
\lambda_{i, j}(t)=\lambda_{0, j}(t) \exp \left\{\beta^{j} w_{i}+\alpha_{1}^{j} w_{i} U R_{i t}+\alpha_{2}^{j} w_{i} U R_{i t}^{2}+\delta^{j} X_{i}+\gamma^{j} W_{i t}\right\} .
$$

Under this specification, the elasticity of separation can be calculated as $\beta^{j}+$ 
$\alpha_{1}^{j} U R+\alpha_{2}^{j} U R^{2}$.

Finally, we turn our attention to threats to identification. Consistent estimates of our parameters of interest hinge on the assumption that the included regressors are exogenously determined. The problematic regressor in this context is the log of salary, which might be correlated with unobserved factors such as the productivity of the worker. In this instance, highly productive workers are more likely to receive a higher salary and, holding all else constant, are more likely to be more mobile as they should receive more outside offers. Therefore, estimates of the quit elasticity may be biased upwards towards zero, suggesting that workers are less mobile than they actually are. In this setting, a valid instrumental variable will affect salary but be uncorrelated with the portion of unobserved individual heterogeneity that affects both salary and the expected number of job offers at other firms. Ransom and Sims (2010) is able to use union contract wages to instrument for the salary of school teachers and shows that this intuition holds true as the OLS estimates on wage are larger than the IV estimates. ${ }^{12}$ Therefore, our results will likely underestimate the role of compensation in a worker's decision to quit. ${ }^{13}$ We believe that the return elasticity will be biased in the opposite direction. This stems from the fact that we believe firms will choose to layoff and fire less productive workers who likewise have lower wages.

Under the Burdett-Mortensen search model (Burdett and Mortensen 1998), there exists a non-degenerate distribution of wages across firms. ${ }^{14}$ This stems from variation in earnings in the labor market through an indeterminacy in which firms may earn the same profits either by having high wages and low recruiting costs or low wages and high recruiting costs. We believe the exogenous wage variation in our data closely follows the Burdett-Mortensen framework. Although we have data from only six firms, these six firms are intermediaries and employee pay is influenced by the client firm of the intermediary. Therefore, the variation in earnings in our data is the result of different pay practices from the hundreds of different client firms at which the workers in our dataset are physically employed.

Our data contain a mixture of workers on L-1 and $\mathrm{H}-1 \mathrm{~B}$ visas. According to the non-immigrant visa statistics found on the USCIS website, $60 \%$ of all $\mathrm{H}-1 \mathrm{~B}$ visas were granted to persons of Indian nationality in 2012, and four times as many $\mathrm{H}-1 \mathrm{~B}$ visas were granted to Indian nationals than L-1 visas. An analysis of data from 2007 shows that the largest Indian IT companies had a greater reliance on L-1 visas than the national figures suggest: the five largest companies had an even balance between $\mathrm{H}-1 \mathrm{~B}$ and L-1 visas. We believe that $\mathrm{H}-1 \mathrm{~B}$ workers and L-1 workers are paid similar wages. Accordingly, as L-1 workers are explicitly prohibited from inter-firm mobility, and should therefore not respond to lower wages with increased

\footnotetext{
${ }^{12}$ We have attempted a similar strategy, using local area average wages from Labor Condition Applications to instrument for the salary of a worker in a given metro area, but did not obtain significant statistical power in the first stage.

${ }^{13}$ Ransom and Sims (2010) does not use a hazard model to study the separation, however, the intuition on the direction of the bias is consistent across the competing risk hazard model and a linear model.

${ }^{14}$ See Appendix A for details on this model.
} 
movement, we believe that the inclusion of these workers in our data will result in an attenuation bias in our findings.

If it were the case that L-1 workers were paid significantly higher wages than $\mathrm{H}-1 \mathrm{~B}$ visa workers, we would be confounding their higher wages and decreased propensity to quit with a causal effect of the higher wages and possibly be overstating the quit elasticity of these workers. However, given the immobility of L-1 visa holders, firms are likely better able to exercise their market power and markdown L-1 salaries relative to H-1B salaries. Furthermore, our analysis of USCIS data shows that there exists variation across firms in the relative prevalence of the two types of visas across firms in this industry. Our inclusion of firm indicator variables (we do not know the actual firm, but we have been given an anonymized firm indicators) should partially alleviate this concern. Again, our prior is that the H-1B and L-1 workers are paid similar wages, thus the effect of their inclusion in our estimation should be to attenuate our elasticity estimates.

\section{Results}

Tables 2 and 3 report the quit and return elasticities obtained using our preferred set of controls. ${ }^{15}$ Table 2 includes all observations, with quits being considered the event and treating returns as a competing risk to the event. Table 3 also includes all observations, but considers the event to be a return to Indian and treats quits as the competing risk. Each table presents parameter estimates for five different groups of workers: all observations, male, female, married and single.

Table 2 shows a coefficient on log salary of -0.332. As we discussed in the Model section, this can be interpreted as a quit elasticity. This is slightly smaller than previous results in the literature that study other groups of workers (Webber 2011), as we will show in detail below. This elasticity implies that a $10 \%$ increase in salary yields a $3.32 \%$ decrease in the probability of quitting. The fact that these results are not zero suggests that these workers have some degree of mobility and that lower paid workers are able to relocate to other employment. These results are surprising given the legal costs of mobility for $\mathrm{H}-1 \mathrm{~B}$ workers and perceptions that they are completely immobile. Also note that an unknown proportion of these workers are on L-1 visas and therefore are indeed completely immobile. Thus, we are underestimating the responsiveness of $\mathrm{H}-1 \mathrm{~B}$ workers to changes in their salary. In summary, we see that lower paid workers in our market are more likely to quit (presumably to find better jobs) than are higher paid workers in our market, just as prior literature has shown for other labor markets with fewer mobility restrictions. Table 2 shows that men have a more elastic separation elasticity than women, consistent with Ransom and Sims (2010) and Hirsch et al. (2006), and that married workers are more elastic than single workers.

Table 3 reports the elasticity of return to India with respect to the salary for our full sample of workers, as well as the four subgroups of workers discussed above.

\footnotetext{
${ }^{15}$ Additional specifications and results appear qualitatively robust and are shown in Table 7. These specifications include various combinations of the included regressors.
} 
The estimates for the full sample show that workers are $15 \%$ less likely to return to India for a $10 \%$ increase in salary. The point estimate of the return elasticity is similar across the four heterogenous subgroups. Males and single individuals are slightly less responsive to lower wages in the decision to return to India.

In addition to the return and the quit elasticities, Tables 2 and 3 also provide estimates of the relationship between the unemployment rate and quit and return rates. The estimated coefficients on the unemployment rate and its square in Table 2 show a negative and concave marginal association between the unemployment rate and the quit rate and are jointly significant at the $5 \%$ level for all observations and for the male and single subgroups. However, note that we are not yet measuring the effect of unemployment on separations through the elasticity, which we will turn our attention to in the next set of tables. The coefficients on the unemployment rate and the unemployment rate squared terms in Table 3 suggest a positive marginal effect of unemployment on return hazards at full employment. However, using a $10 \%$ threshold for statistical significance, the coefficients on the unemployment rate and unemployment rate squared are only jointly different from zero for female and single observations.

Tables 4 and 5 repeat the analyses reported in Tables 2 and 3 with an additional set of terms that allow us to estimate the cyclicality of the elasticities. Each table presents two chi-squared test statistics on a null hypothesis of joint insignificance of a set of parameters. The first chi-square statistic tests for the joint insignificance of $\log$ wage interacted with unemployment and the unemployment rate squared. We always reject the null of joint insignificance in Table 4, and reject for our pooled sample and the two larger groups in Table 5. This strongly suggests that there is a relationship between the quit and return elasticities and the business cycle, as captured by the unemployment rate. The second chi-squared test rejects a null of the joint significance of all terms that involve log salary.

At the bottom of Tables 4 and 5 , we report quit and return elasticities at unemployment rates of $4 \%, 6 \%, 8 \%$, and $10 \%$. In Table 4 , we see that the quit elasticity becomes more inelastic as the unemployment rate increases. When the unemployment rate is $4 \%$, then a $10 \%$ increase in the wage is associated with a $14 \%$ decrease in the quit rate. When unemployment is $6 \%$ the $10 \%$ increase in wage corresponds to a $6 \%$ decrease in quits. At an unemployment rate of $8 \%$ we see that the quit elasticity is not significantly different from zero. Recall that despite high levels of unemployment since the onset of the Great Recession, the unemployment rate did not exceed $8 \%$ between January 1984 and February 2009. ${ }^{16}$ These results suggest that, after unemployment becomes exceedingly high, labor market churn breaks down for these workers.

In the bottom panel of Table 5, we see that lower wage workers become more likely to return to India as the unemployment rate increases. At an unemployment rate of $4 \%$, a $10 \%$ increase in the wage is associated with a $11 \%$ decrease in the return rate. At $6 \%$ unemployment, a $10 \%$ increase in wages results in a $15 \%$ decline. For unemployment rates of $8 \%$ and $10 \%$, the $10 \%$ increase in wage results in a $17 \%$

${ }^{16}$ See http://data.bls.gov/timeseries/LNS14000000 for data source. 
decrease in returns to India.

Figures 3 and 4 graphically display the marginal effect of unemployment on the quit elasticities. Figure 3 displays the marginal effect of unemployment on the quit elasticity. In the figure, we see the positive relationship between the elasticity and the unemployment rate that we had previously described: the elasticity is below -1 at full employment, but reaches zero as the unemployment rate reaches about $7.9 \%$. Figure 4 explores heterogeneity in this relationship across our different observable groups. It appears that the relatively inelastic estimates for females are less sensitive to fluctuations in the business cycle. Similarly, single workers appear to also have somewhat less variability in their quit elasticities over the business cycle.

Figures 5 and 6 repeat the exercise for return elasticities. Figure 5 shows a negative relationship between the return elasticity and the unemployment rate at full employment, though there does appear to be a positive relationship at higher levels of unemployment. Figure 6 shows that this basic pattern holds for each of our subgroups.

Finally, in Table 7 we explore the robustness to different controls and models as well as the differences in the estimated elasticities between the competing risk model that we employ and the standard Cox proportional hazard model that has recently been used by others to estimate separation elasticities. Our first specification includes only unemployment, its square, and the log of wage. The second specification also includes the individual characteristics previously mentioned, and the third specification adds firm indicators. The fourth specification, which includes month and year indicators, does not change the Cox estimates substantially, nor does the fifth specification, which includes state indicators as well. We see that the Cox proportional hazard model generally yields more elastic estimates than the competing risk model. ${ }^{17}$

In summary, our duration analysis has revealed important facts about levels and cyclicality of both the return and quit elasticities. The return elasticity is elastic and generally pro-cyclical. The quit elasticity is counter-cyclical and significantly different from zero when unemployment is below historically high levels.

\section{Discussion of the Results}

In this section, we relate the above results to models of frictions in labor markets, claims made about the exploitation of $\mathrm{H}-1 \mathrm{~B}$ workers, and broader implications for the labor market. We first show how our results compare to the literature. Then we discuss Manning's (2003) wage setting model. Following this, we discuss evidence that his model may apply in our setting. We then assess how our findings shed

\footnotetext{
${ }^{17}$ At the time of this writing, results for the fifth specification which includes fixed effects are not yet available for the competing risk hazard model due to an extended (over 10 days) run time. We hope to include these in a future draft; however, we believe that this table provides some evidence that our current results in the competing risk model should be robust to the inclusion of these additional controls.
} 
light on questions about guest worker pay, mobility, and attachment to the U.S. labor market in recessions. Finally, inspired by our observation of increased return migration during the Great Recession, we explore how changes in migration patterns during an economic downturn may create discouraged immigrants and thereby lead to hard to interpret changes in EPOP.

\subsection{Our Results Relative to the Literature}

Table 4 provides strong evidence that our estimates are similar to the literature. We make an explicit comparison to prior estimates in Figure 7, which shows where our own estimate of the quit elasticity (at an unemployment rate of $7 \%$ ) falls in the distribution of previous estimates, as reported by Manning (2011). ${ }^{18}$ We see that our results are significantly more elastic than prior estimates when the unemployment rate is at $4 \%$, in the middle of the distribution of estimates as an unemployment rate of $6 \%$, and perfectly inelastic at an unemployment rate of $8 \% .{ }^{19}$ This suggests that the exogenously imposed switching cost of the visa program may be trumped by the thickness of this labor market and the prevalence of information regarding job opportunities in this labor market, so long as the economy is at full employment. As we have noted, if there exists bias in our results, it likely attenuates our estimates, suggesting that without the omitted variables bias issue and attenuation effects of including L-1 visa workers, $\mathrm{H}-1 \mathrm{~B}$ workers may be more responsive to lower wages in their quit decisions than our results state here. It is unclear how the degree of bias in our results compares to the degree of bias in other studies.

\subsection{Wage Setting with Finite Quit Elasticities}

Robinson (1933) shows that a profit maximizing firm that is the sole employer in the labor market will set wages as a fraction of marginal revenue product:

$$
w=M P R_{L} \frac{\epsilon_{L w}}{1+\epsilon_{L w}}
$$

The term $\epsilon_{L w}$ is the elasticity of labor supply to the firm. This is similar to a standard Industrial Organization price setting model under monopoly or monopolistic

\footnotetext{
${ }^{18}$ We use 25 estimated quit elasticities reported by Manning (2011) in Tables 6 and 7 of his book chapter. When estimates for multiple groups were reported, we took the raw average of the reported estimates. When ranges were given, we took the midpoint. For a paper reporting one sided bounds, we used the bound itself as the estimate. All reported elasticities in these tables were obtained by estimating the effect of wages on separations. Rather than report the implied supply elasticities, as Manning did, we instead report minus one half of his numbers, i.e. the raw separation elasticity results that were used to generate the implied supply elasticity numbers, and are thus most comparable to the numbers presented in tables 2 through 6 .

${ }^{19}$ The positive estimate at $10 \%$ is not displayed in this Figure; as we have noted earlier, we suspect that there is upward bias in our estimates and at $10 \%$ the upward bias is large enough to produce a positive estimate.
} 
competition where firms have some power to set price above marginal cost (Berry, Levinsohn and Pakes 1995).

Robinson developed her model to explain discrimination against workers with identical marginal revenue products. She argues that workers belonging to observably different groups with different $\epsilon_{L w}$ terms would be paid different wages. We later show evidence of the presence of this form of discrimination in our data. We argue that this supports the general applicability of the wage setting model given in Equation 3 to our data.

There has been increased interest in monopsonistic models of the labor market over the last decade, following Manning's (2003) model where search frictions lead to firm wage setting power, even when there are many employers in the market. Manning and earlier work by Card and Krueger (1995) show that the supply elasticity $\left(\epsilon_{L w}\right)$ is equal to twice the absolute value of the quit elasticity $\left(\epsilon_{q w}\right){ }^{20}$ Thus we may infer what percent of their marginal revenue product workers earn as a function of the quit elasticity. We do this to evaluate firms' potential to exploit these guest workers.

We now turn our attention to arguments about why the separation elasticity might indeed be finite. In short, the perfectly elastic labor supply curve to the firm, indicative of perfect competition, can only exist in a frictionless market in which workers may costlessly and instantaneously move to a new job. In the real world, a small decrease in the wage for a given firm will likely not cause all workers to quit this firm. This is due to the presence of frictions. Commonly pointed to frictions are: 1) imperfect information, which prevents workers from having knowledge of all possible competing job offers (i.e., the arrival rate of job offers is finite) and, 2) frictions reducing mobility that may be imposed upon the individual or market from the outside. For example a government regulation which imposes fees on mobility between jobs would be an exogenous friction. ${ }^{21}$ While distinguishing between the causes of the finite elasticity would be an interesting endeavor in future work, we cannot do so in the present study.

\subsection{Implications for Pay of H-1B Workers}

The Manning wage-setting model implies that discrimination along non-productivity related characteristics is associated with the quit elasticity. If the Manning model applies in this setting, we would expect to find relatively lower wages for groups with relatively lower elasticities. In Table 6 , the left column presents the familiar malefemale decomposition while the right presents the married-single decomposition. The top row shows the average log earnings for the higher paid group (males and

\footnotetext{
${ }^{20}$ Card and Krueger (1995) shows that the supply elasticity is equal to the sum of absolute values of the quit elasticity and the recruitment elasticity. Manning (2003) argues that under reasonable assumptions, the quit and recruitment elasticities are equal to one another in absolute value.

${ }^{21}$ This is similar to work in Industrial Organization by Shcherbakov (2009), and Nosal (2012), who empirically show that the existence of switching costs for consumers allows firms greater liberty in setting prices.
} 
married individuals) and the bottom row shows the same for the lower paid group (females and single individuals). We see a gender wage gap of $7.44 \mathrm{log}$ points and a marital status wage gap of $12.15 \log$ points. The next row reports the explained portion of the gap as given by the Oaxaca (1973) decomposition. In each regression we include as explanatory variables age and age-squared, gender and marital status indicator variables, and fixed effects for the state, firm, month, and year of the observation. We find that almost exactly half of a $7.44 \mathrm{log}$ point difference in male and female earnings is explained by our control variables, leaving a $3.72 \log$ point gap that cannot be explained by differences in the observed characteristics. ${ }^{22} \mathrm{We}$ also find that around $1.85 \mathrm{log}$ points of the married to single pay difference remains unexplained. Both unexplained portions are significantly different from zero at the $1 \%$ statistical significance level.

In the bottom panel of Table 6, we report the implied amount of potential thirddegree factor price discrimination (at different levels of unemployment). We define third-degree factor price discrimination as the predicted difference in wages resulting from differences in $\epsilon_{L w}$ between two groups. We present the implied amount of this potential discrimination at an unemployment rates of $4 \%$ and 6 percent. ${ }^{23}$ Note that by examining this measure for different levels of unemployment, one can see that the implied amount of potential discrimination varies over the business cycle as the elasticities themselves vary over the business cycle. At an unemployment rate of $4 \%$, we find that due to differential monopsonistic market power, a profit maximizing firm would pay men $17.8 \mathrm{log}$ points more than women and married workers $47.2 \mathrm{log}$ points more than single workers. At an unemployment rate of $6 \%$, the estimated elasticities suggest that males should earn 23.5 log points more than females and married individuals earn $126 \log$ points more than single individuals. The model predicts much wider pay gaps than we actually observe, consistent with there being more constraints to wage setting than the simple model would suggest. ${ }^{24}$ Nevertheless, this exercise does suggest that different estimated elasticities in our data are indeed correlated with pay gaps in the direction predicted by the model.

Evidence suggests that firms may indeed be able to pay guest workers less than citizens or green card holders, if they were to possess lower elasticities. While we are not able to estimate the elasticity for citizens and green card holders, the relatively large elasticity estimates (comparable to other studies) for the guest workers suggest

\footnotetext{
${ }^{22}$ While we do not observe the typically important control variable of years of education, we believe there to be vary little variation in this variable among these workers.

${ }^{23} \mathrm{We}$ are unable to present the implied amount of potential third-degree factor price discrimination at unemployment levels of $8 \%$ and $10 \%$ because at an unemployment rate of $8 \%$ and above, the point estimate of the quit elasticity is positive, which leads to a negative argument in a log function.

${ }^{24}$ Figure A1 displays the the unexplained portion of the Oaxaca decomposition for various unemployment rate bands. Each point estimate displayed comes from separate Oaxaca decompositions in which the data is limited to an unemployment rate within 1-percent of the rate displayed in the figure. The figure shows that the amount of the unexplained portion of the pay gap increases over the unemployment rate.
} 
that any pay differences, while they may exist, are likely to be relatively modest.

\subsection{Claims Regarding the H-1B Program}

We now take the evidence presented earlier and summarize how it relates to some of the central contentions surrounding guest worker visa programs. One premise of opponents of guest worker programs is that workers on these visas are unable to freely move between employers once they arrive in the U.S. The data that we have presented here contradicts this assertion, at least when the economy is at full-employment. Our summary data shows that around $22 \%$ quit their jobs and remain in the U.S. As these workers cannot separate to unemployment and remain in compliance with U.S. immigration law, presumably they have found work at another employer. Further, we find that the lowest paid among these workers are the most likely to quit their job, consistent with workers moving in the labor market to escape bad or low paying employers. Specifically, we find that a $10 \%$ decrease in wages is associated with a $6.1 \%$ increase in the quit rate at an unemployment rate of 6 percent. Considering that our data include an unknown number of L-1 visa holders, who are explicitly prohibited from separating from employment, this strongly suggests that $\mathrm{H}-1 \mathrm{~B}$ visa workers who are employed by large Indian IT firms (who are the largest users of the $\mathrm{H}-1 \mathrm{~B}$ and $\mathrm{L}-1$ visa programs) are in fact quite mobile.

The Oaxaca decompositions presented above relate to a second claim made regarding the $\mathrm{H}-1 \mathrm{~B}$ visa program: that workers on these visas are dramatically underpaid. The evidence provided above suggests that the Manning wage setting model has some predictive power in our data. The evidence also suggests that a wedge exists between what workers are paid and what their marginal revenue product is. However, the degree of wage-setting power is limited by the mobility of workers. Again, our estimates show healthy degrees of mobility at full employment but elasticities that are not significantly different than zero when the unemployment rate approaches 8 percent, a rate of unemployment which has been covered by few previous studies. As with the above estimates of implied gaps between groups, the finite mobility of the workers likely overstates the size of the wedge between workers' wages and their marginal productivities as firms are constrained by factors not captured by the model. While this is a deviation from a perfectly competitive model, it may not be very different from the labor market at large.

A third concern of opponents of the $\mathrm{H}-1 \mathrm{~B}$ program is that it does not adjust the number of visas available over the business cycle. Our data show that the rate of return migration increases during the years of the Great Recession, suggesting that return migration during recessions should at least partially mitigate concerns that the program does not adjust to labor market conditions.

\subsection{Discouraged Immigrants and EPOP}

Our estimates show that there are generally both higher return rates and a higher

return elasticities during periods of high unemployment. This brings our attention 
to a potential issue related to not accounting for cyclical return migration. Here we explore the consequences of this phenomenon on measurement of the EPOP.

We use the American Community Survey (ACS) (Ruggles, Alexander, Genadek, Goeken, Schroeder and Sobek 2010), conducted in April of each survey year, to construct the trend growth rates (from 2000 through 2008) in the population of male immigrants with a Bachelor's degree who are older than 25 and younger than 50 . We first consider Indian born workers. Indian workers, while a significant part of this labor market, are a minority of all foreign born workers who fit the criteria above. We then turn our attention to all foreign born workers. In Figure 8 we show the break from trend migration starting in 2008 for Indian workers and all foreign born workers, respectively. We see that the Great Recession has created around 40 thousand fewer Indian immigrants and 290 thousand fewer immigrants from all source countries than the trend growth would have predicted. This may stem from either higher rates of outmigration, as seen in our data, or lower rates of immigration.

The clear advantage of the EPOP over the unemployment rate is that it is not biased by discouraged workers, who self-select out of both the numerator and denominator of the unemployment rate in response to tough labor markets. However, the EPOP will not be robust to discouraged immigrants: if the size of the potential labor force in a given market has been affected by labor market conditions, then the standard measure of the EPOP might mis-state the true health of the labor market by not correcting for immigrants who disappear from the sample.

In Figure 9, we show how the EPOP for prime-aged college graduate male workers has changed since the onset of the Great Recession. The ratio has declined by 2.28 percentage points: from $93.98 \%$ to $91.70 \%$ from 2008 through 2011 . However, we see that this decline would have been much larger were we to include the discouraged immigrants among the workers not employed in this market. Specifically, we see that the inclusion of the missing Indian immigrants would have led to an extra quarter of a percentage point decline in EPOP of 2.53 percentage points (as EPOP would have declined to $91.45 \%$ ). When assessing the impact for all immigrants, we find that EPOP would have declined by 4.09 percentage points to $89.89 \%$.

In summary, discouraged immigrants are in part a byproduct of the type of return migration that we observe in our data. The standard measure of the EPOP does not consider these immigrants. By including them, we conclude that the employment to population ratio has suffered a larger decline during the Great Recession than standard analysis would suggest. Specifically, we find that in the labor market in question, the decline in the EPOP is between $11 \%$ (when considering only Indian immigrants) and $79 \%$ (when considering all immigrants) larger than when conventionally measured.

\section{Conclusions}

One major criticism of the $\mathrm{H}-1 \mathrm{~B}$ visa program is that it limits the mobility of visa holders by imposing costs on prospective employers, placing them in a situation of 
indentured servitude. Search models show that labor markets cease to yield perfectly competitive outcomes when significant levels of frictions exist; these frictions may increase during bad economic times. Typically, we think of these frictions as coming from shortcomings in the market, such as imperfect information about available jobs or the quality of a potential match. In the case of the labor market for $\mathrm{H}-1 \mathrm{~B}$ workers, frictions are imposed from outside the labor market by government regulations: there are explicit costs to changing the sponsoring employer of a visa. General regulatory costs may dissuade some firms from hiring these workers at all, thus thinning the labor market. It is not surprising that the popular consensus about this labor market is that it is plagued by immobility resulting in the exploitation of workers.

However, our empirical analysis finds evidence of worker mobility when the unemployment rate is below $8 \%$ : lower paid workers are more likely to quit their current job than are higher paid workers, consistent with a well functioning labor market where churn moves workers to better employers. This churn breaks down during the Great Recession. The degree of mobility that we observe at full employment is comparable to findings in other markets not affected by government imposed frictions. These workers, who after all migrated to the U.S., may be particularly mobile in terms of willingness to search and move within the U.S., have more industry than firm specific human capital, or have particularly thick networks because of the large number of Indian nationals in this labor market (Yueh 2008). At the same time, our empirical analysis clearly deviates from the standard competitive model of a frictionless labor market. While our results reject comparisons of this market to indentured servitude, they also reject the conclusion that this labor market is perfectly competitive.

Several caveats color our conclusions related to the H-1B program. First, our data come from six large Indian IT firms. While they are a substantial part of the market - and much of the controversy over the use of these visas centers around them - we do not claim that these results are representative of the market as a whole. Second, we do not speak to the situation of L-1 workers directly. While they are in our dataset, we cannot distinguish between H-1B and L-1 workers, and they are likely to be more vulnerable given that they cannot terminate employment without giving up their legal status in the U.S. As discussed previously, the restrictions on L-1s imply that $\mathrm{H}-1 \mathrm{~B}$ workers are even more mobile than our results suggest.

This research also contributes three findings related to return migration over the business cycle. First, we find that lower paid workers are more likely to return to India than are higher paid workers, consistent with Abramitzky et al. (2012). Second, we find that the relationship between salary and return rates generally becomes tighter during economic downturns. Finally, we demonstrate that the phenomenon of counter-cyclical migration may lead to underestimates of declines in the employment to population ratio during recessions. Essentially, were it not for return migration, concerns regarding immigration during periods of recession would be aggravated and the employment to population ratio would be significantly lower. 
Beyond the $\mathrm{H}-1 \mathrm{~B}$ program, the present study adds to the literature on frictions in the labor market as well as to an understanding of the role of labor market institutions on labor market outcomes. We use firm-level data in this study, which is rare in studies of immigration. We are the first to employ a competing risks hazard model to estimate quit elasticities. We are also the first study to examine quit elasticities as a function of unemployment, and we further the evidence in an earlier study showing that firm market power increases during economic downturns (Depew and Sorensen 2012). These findings may shed light on "jobless recoveries" and the role that market power plays in macroeconomic downturns (Erickson and Mitchell 2007). The relationship between the business cycle and the quit elasticity is an area that is ripe for future research. 


\section{References}

Abramitzky, Ran, Leah Platt Boustan, and Katherine Eriksson, "A Nation of Immigrants: Assimilation and Economic Outcomes in the Age of Mass Migration," Working Paper 18011, National Bureau of Economic Research April 2012.

Banerjee, Payal, "Indian Information Technology Workers in the United States: The H-1B Visa, Flexible Production, and the Racialization of Labor," Critical Sociology, March 2006, 32 (2-3), 425-445.

, "Indian IT workers in the U.S.: Race, gender, and state in the making of immigrant labor." PhD dissertation, Syracuse University, United States - New York 2009. Ph.D.

Berry, Steven, James Levinsohn, and Ariel Pakes, "Automobile Prices in Market Equilibrium," Econometrica, 1995, 63 (4), 841-890.

Blau, Francine D. and Lawrence M. Kahn, "Institutions and Laws in the Labor Market," Handbook of Labor Economics, 1999, 3 (A), 1399-1461.

Boal, William M., "Testing for Monopsony In Turn-of-the-Century Coal Mining," The RAND Journal of Economics, 1995, 26 (3), 519-536.

Booth, Alison L., Marco Francesconi, and Carlos Garcia-Serrano, "Job Tenure and Job Mobility in Britain," Industrial and Labor Relations Review, Oct. 1999, 53 (1), 43-70.

Borjas, George J, "Immigration in High-Skill Labor Markets: The Impact of Foreign Students on the Earnings of Doctorates," in "Science and Engineering Careers in the United States: An Analysis of Markets and Employment," NBER, June 2009, pp. 131-161.

Borjas, George J. and Kirk B. Doran, "The Collapse of the Soviet Union and the Productivity of American Mathematicians," The Quarterly Journal of Economics, August 2012, 127 (3), 1143-1203.

Burdett, Kenneth and Dale T. Mortensen, "Wage Differentials, Employer Size, and Unemployment," Intenational Economic Review, 1998, 39 (3), 257273.

Card, David and Alan B. Krueger, Myth and Measurement: The New Economics of the Minimum Wage, Princeton University Press, 1995.

Chakravartty, Paula, "Symbolic analysts or indentured servants? Indian hightech migrants in Americas information economy," Knowledge, Technology 8 Policy, 2006, 19 (3), 27-43.

Depew, Briggs and Todd A. Sorensen, "The Elasticity of Labor Supply to the Firm Over the Business Cycle," UCLA Institute for Research on Labor and Employment Working Papers, 2012, 2012-2013. 
Devereux, Paul J. and Robert A. Hart, "Real Wage Cyclicality of Job Stayers, Within-Company Job Movers, and Between-Company Job Movers," Industrial and Labor Relations Review, July 2006, 60 (1), 105-119.

Dorning, Jennifer and Charlie Fanning, "Gaming the System: Guest Worker Visa Programs and Professional and Technical Workers in the U.S.," Technical Report, Department for Professional Employees, AFL-CIO, Washington, DC 2012.

Dube, Arindrajit, T. William Lester, and Michael Reich, "Do Frictions Matter in the Labor Market? Accessions, Separations and Minimum Wage Effects," IZA Discussion Paper Series, 2011, 5811.

Erickson, Christopher L. and Daniel J.B. Mitchell, "Monopsony as a metaphor for the emerging post-union labour market," International Labour Review, 2007, 146 (3-4), 163-187.

Falch, Torberg, "The elasticity of labor supply at the establishment level," Journal of Labor Economics, 2010, 28 (2).

_ - "Teacher Mobility Responses to Wage Changes: evidence from a quasinatural experiment," American Economic Review, 2011, 101 (2).

Farber, Henry S., "The Analysis of Inter-firm Worker Mobility," Journal of Labor Economics, Oct. 1994, 12 (4), 554-593.

Fine, Jason P. and Robert J. Gray, "A proportional Hazards Model for the Subdistribution of a Competing Risk," Journal of the American Statistical Associaiton, June 1999, 94 (446), 496-509.

Hatch, Orrin, "Senate Report 106-260: American Competitiveness in the 21st Century," Senate Committe on the Judiciary Report 106-260, U.S. Senate, Washington, DC April 2000.

Hira, Ron, "The H-1B and L-1 Visa programs: Out of Control," Technical Report 280, Economic Policy Institute, Washington, DC October 2010.

Hirsch, Boris, "Joan Robinson Meets Harold Hotelling: A Dyopsonistic Explanation of the Gender Pay Gap," BGPE Discussion Papers 24, Bavarian Graduate Program in Economics (BGPE) June 2007.

and Elke J. Jahn, "Is There Monopsonistic Discrimination against Immigrants? First Evidence from Linked Employer-Employee Data," IZA Discussion Papers 6472, Institute for the Study of Labor (IZA) April 2012.

, Thorsten Shank, and Claus Schnabel, "Gender Differences in Labor Supply to Monopsonistic Firms: An Empirical Analysis Using Linked Employer-Employee Data from Germany," IZA Discussion Papers 2443, Institute for the Study of Labor (IZA) November 2006. 
and

"Differences in Labor Supply to Monopsonistic Firms and the Gender Pay Gap: An Empirical Analysis Using Linked EmployerEmployee Data from Germany," Journal of Labor Economics, 2010, 28 (2), 291-330.

Hotchkiss, Julie L. and Myriam Quispe-Agnoli, "Employer Monopsony Power in the Labor Market for Undocumented Workers," SSRN eLibrary, December 2009.

Hunt, Jennifer and Marjolaine Gauthier-Loiselle, "How Much Does Immigration Boost Innovation?," American Economic Journal: Macroeconomics, 2010, pp. 31-56.

Kandilov, A. M. G., "The Value of a Green Card Immigrant Wage Increases Following Adjustment to US Permanent Residence," Working Paper, 2007.

Kerr, Sari P., William R. Kerr, and William F. Lincoln, "Skilled Immigration and the Employment Structures of U.S. Firms," Working Paper, February 2013.

Kerr, William and William Lincoln, "The Supply Side of Innovation: H-1B Visa Reforms and US Ethnic Invention," Journal of Labor Economics, 2010, 28, 473-508.

Lofstrom, Magnus and Joseph J. Hayes, "H-1Bs: How Do They Stack Up to US Born Workers?," SSRN eLibrary, December 2011, Discussion Paper 6259.

Lowell, B. Lindsay, "H-1B Temporary Workers: Estimating the Population," May 2000.

MacDonald, Ian, Jorge R. Lopez, Scott Decker, and Michelle Valerio, "Gang Of Eight Introduces Comprehensive Immigration Reform Bill," http://www.mondaq.com/unitedstates/x/235554/work+visas/Gang+of+Eight+Introduces+Comprehensi April 2013.

Manning, Alan, Monopsony in Motion: Imperfect Competition in Labor Markets, Princeton University Press, March 2003.

_ , "Chapter 11 - Imperfect Competition in the Labor Market," in David Card and Orley Ashenfelter, ed., Handbook of Labor Economics, Vol. Volume 4, Part B, Elsevier, 2011, pp. 973-1041.

Matloff, Norman, "On the Need for Reform of the H-1B Non-Immigrant Work Visa in Computer-Related Occupations," University of Michigan Journal of Law Reform, 2002, 36, 816.

__ , "Best? Brightest?," Backgrounder, 2006.

Miano, John, "The Bottom of the Pay Scale: Wages for H-1B Computer Programmers," Center for Immigration Studies, December 2005. 
Mithas, Sunil and Henry C Lucas, "Are Foreign IT Workers Cheaper? U.S. Visa Policies and Compensation of Information Technology Professionals," Management Science, May 2010, 56 (5), 745-765.

Mukhopadhyay, Sankar and David Oxborrow, "The Value of an Employment-Based Green Card," Demography, 2012, 49 (1), 219-237.

Nosal, Kathleen, "Estimating Switching Costs for Medicare Advantage Plans," University of Mannheim Working Paper, 2012.

Oaxaca, Ronald L., "Male-female wage differentials in urban labor markets," International Economic Review, 1973, 14 (3), 693-709.

Ransom, Michael R. and David P. Sims, "Estimating the Firm's Labor Supply Curve in a New Monopsony Framework: School Teachers in Missouri," Journal of Labor Economics, April 2010, 28 (2), 331-356.

and Val E. Lambson, "Monopsony, Mobility, and Sex Differences in Pay: Missouri School Teachers," American Economic Review, 2011, 101 (3), 454-59.

Ransom, MichaelR. and RonaldL. Oaxaca, "New Market Power Models and Sex Differences in Pay," Journal of Labor Economics, April 2010, 28 (2), 267289.

Robinson, Joan, The Economics of Imperfect Competition, London, UK: Macmillan and Co. ltd., 1933.

Ruggles, Steven, J. Trent Alexander, Katie Genadek, Ronald Goeken, Matthew B. Schroeder, and Matthew Sobek, "Integrated Public Use Microdata Series: Version 5.0 [Machine-readable database]," 2010.

Shcherbakov, Oleksandr, "Measuring Consumer Switching Costs in the Television Industry," University of Mannheim Working Paper, 2009.

Solon, Gary, Warren Whately, and Ann Huff Stevens, "Wage Changes and Intrafirm Job Mobility over the Business Cycle: Two Case Studies," Industrial and Labor Relations Review, 1997, 50 (3), 402-415.

Wasem, Ruth Ellen, "Immigration of Foreign Nationals with Science, Technology, Engineering, and Mathematics (STEM) Degrees," May 2012.

Webber, Douglas A., "Firm Market Power and the Earnings Distribution," SSRN eLibrary, December 2011.

Yueh, Linda Y., "Do social networks increase labour supply elasticity?," Applied Economics Letters, 2008, 15 (1), 5-10. 
Table 1: Summary Statistics

\begin{tabular}{lccc}
\hline \hline & Mean & St. Dev. & $\mathrm{N}$ \\
\hline Salary & 72182.30 & 15416.40 & 72575 \\
Quit & 0.22 & 0.41 & 72575 \\
Return & 0.29 & 0.46 & 72575 \\
Start Age & 29.50 & 5.28 & 72575 \\
Female & 0.18 & 0.39 & 72575 \\
Married & 0.62 & 0.49 & 72575 \\
Unemployment Rate & 7.79 & 2.51 & 1667335 \\
\hline \hline
\end{tabular}

a The data consists of 72,575 unique employee observations from January 2003 through September 2011. In the table, the statistics for the Unemployment Rate are calculated from 1,667,335 employee-month observations.

Table 2: Competing Risk Regression Results: Quit to another Firm

\begin{tabular}{lccccc}
\hline \hline & All & Male & Female & Married & Single \\
\hline $\ln$ (Salary) & $-0.3317^{* * *}$ & $-0.3291^{* * *}$ & $-0.2018^{*}$ & $-0.4381^{* * *}$ & 0.0291 \\
& $(0.0834)$ & $(0.0963)$ & $(0.1052)$ & $(0.0909)$ & $(0.1167)$ \\
Unemp. Rate & $-0.1202^{* *}$ & $-0.1208^{* *}$ & $-0.1354^{*}$ & -0.1013 & $-0.1253^{* *}$ \\
& $(0.0572)$ & $(0.0569)$ & $(0.0730)$ & $(0.0671)$ & $(0.0619)$ \\
Unemp. Rate-Sq. & 0.0057 & 0.0054 & $0.0079^{*}$ & 0.0045 & 0.0059 \\
& $(0.0035)$ & $(0.0035)$ & $(0.0043)$ & $(0.0038)$ & $(0.0040)$ \\
Female & -0.0070 & & & $0.1622^{* * *}$ & $-0.2422^{* * *}$ \\
& $(0.0323)$ & & & $(0.0449)$ & $(0.0401)$ \\
Married & 0.0146 & $-0.0530^{* *}$ & $0.3179^{* * *}$ & & \\
& $(0.0246)$ & $(0.0250)$ & $(0.0616)$ & & \\
Start Age & 0.0064 & -0.0010 & $0.0741^{* * *}$ & $-0.0534^{* * *}$ & 0.0196 \\
& $(0.0120)$ & $(0.0131)$ & $(0.0243)$ & $(0.0164)$ & $(0.0122)$ \\
Start Age-Sq. & $0.0004^{* * *}$ & $0.0005^{* * *}$ & -0.0003 & $0.0012^{* * *}$ & $0.0002^{*}$ \\
& $(0.0001)$ & $(0.0002)$ & $(0.0003)$ & $(0.0002)$ & $(0.0001)$ \\
\hline Individuals & 72575 & 59227 & 13348 & 44797 & 27778 \\
Quits & 15641 & 12897 & 2744 & 9424 & 6217 \\
Returns & 21393 & 16750 & 4643 & 11568 & 9825 \\
Observations & 1667335 & 1387393 & 279942 & 1125742 & 541593 \\
\hline \hline
\end{tabular}

a Included fixed effects: Firm, Month and Year.

b Standard errors clustered on the state are presented in parentheses.

$\mathrm{c} * 0.10, * * 0.05$ and $* * * 0.01$ denote significance levels. 
Table 3: Competing Risk Regression Results: Return to India

\begin{tabular}{lccccc}
\hline \hline & All & Male & Female & Married & Single \\
\hline $\ln$ (Salary) & $-1.5177^{* * *}$ & $-1.5609^{* * *}$ & $-1.8640^{* * *}$ & $-1.6224^{* * *}$ & $-1.4503^{* * *}$ \\
& $(0.0987)$ & $(0.0810)$ & $(0.1922)$ & $(0.0953)$ & $(0.1269)$ \\
Unemp. Rate & 0.0687 & 0.0451 & $0.1814^{* *}$ & 0.0244 & $0.1233^{*}$ \\
& $(0.0646)$ & $(0.0661)$ & $(0.0784)$ & $(0.0788)$ & $(0.0641)$ \\
Unemp. Rate-Sq. & -0.0038 & -0.0019 & $-0.0120^{* * *}$ & -0.0009 & $-0.0074^{* *}$ \\
& $(0.0035)$ & $(0.0035)$ & $(0.0043)$ & $(0.0044)$ & $(0.0033)$ \\
Female & $0.1986^{* * *}$ & & & 0.0437 & $0.3430^{* * *}$ \\
& $(0.0402)$ & & & $(0.0505)$ & $(0.0426)$ \\
Married & $-0.4206^{* * *}$ & $-0.4560^{* * *}$ & $-0.4574^{* * *}$ & & \\
& $(0.0250)$ & $(0.0265)$ & $(0.0363)$ & & \\
Start Age & $0.1450^{* * *}$ & $0.2201^{* * *}$ & -0.0041 & $0.1773^{* * *}$ & $0.1824^{* * *}$ \\
& $(0.0300)$ & $(0.0325)$ & $(0.0341)$ & $(0.0330)$ & $(0.0365)$ \\
Start Age-Sq. & $-0.0022^{* * *}$ & $-0.0030^{* * *}$ & $-0.0010^{*}$ & $-0.0024^{* * *}$ & $-0.0032^{* * *}$ \\
& $(0.0004)$ & $(0.0004)$ & $(0.0006)$ & $(0.0005)$ & $(0.0005)$ \\
\hline Individuals & 72575 & 59227 & 13348 & 44797 & 27778 \\
Returns & 21393 & 16750 & 4643 & 11568 & 9825 \\
Quits & 15641 & 12897 & 2744 & 9424 & 6217 \\
Observations & 1667335 & 1387393 & 279942 & 1125742 & 541593 \\
\hline \hline
\end{tabular}

${ }^{a}$ Included fixed effects: Firm, Month and Year.

b Standard errors clustered on the state are presented in parentheses.

c * $0.10, * * 0.05$ and $* * * 0.01$ denote significance levels. 
Table 4: Competing Risk Regression Results: Quit to another Firm

\begin{tabular}{|c|c|c|c|c|c|}
\hline & 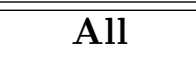 & Male & Female & Married & Single \\
\hline $\ln ($ Salary $)$ & $\begin{array}{c}-3.2981^{* * *} \\
(0.8875)\end{array}$ & $\begin{array}{c}-3.6848^{* * *} \\
(0.8579)\end{array}$ & $\begin{array}{l}-1.9685 \\
(1.4269)\end{array}$ & $\begin{array}{c}-4.8213^{* * *} \\
(0.8998)\end{array}$ & $\begin{array}{l}-1.2060 \\
(1.5066)\end{array}$ \\
\hline $\ln ($ Salary $) \times U R$ & $\begin{array}{c}0.5473^{* *} \\
(0.2554)\end{array}$ & $\begin{array}{c}0.6171^{* *} \\
(0.2513)\end{array}$ & $\begin{array}{c}0.3185 \\
(0.4000)\end{array}$ & $\begin{array}{c}0.8222^{* * *} \\
(0.2501)\end{array}$ & $\begin{array}{c}0.1666 \\
(0.4220)\end{array}$ \\
\hline $\ln ($ Salary $) \times$ UR-Sq . & $\begin{array}{c}-0.0164 \\
(0.0160)\end{array}$ & $\begin{array}{l}-0.0183 \\
(0.0161)\end{array}$ & $\begin{array}{l}-0.0095 \\
(0.0241)\end{array}$ & $\begin{array}{c}-0.0288^{*} \\
(0.0158)\end{array}$ & $\begin{array}{c}0.0026 \\
(0.0249)\end{array}$ \\
\hline Unemp. Rate & $\begin{array}{c}-6.1598^{* *} \\
(2.8685)\end{array}$ & $\begin{array}{c}-6.9379^{* *} \\
(2.8260)\end{array}$ & $\begin{array}{l}-3.6291 \\
(4.4438)\end{array}$ & $\begin{array}{c}-9.1946^{* * *} \\
(2.7954)\end{array}$ & $\begin{array}{l}-1.9465 \\
(4.7065)\end{array}$ \\
\hline Unemp. Rate-Sq. & $\begin{array}{c}0.1846 \\
(0.1804)\end{array}$ & $\begin{array}{c}0.2049 \\
(0.1811)\end{array}$ & $\begin{array}{c}0.1108 \\
(0.2686)\end{array}$ & $\begin{array}{c}0.3211^{*} \\
(0.1768)\end{array}$ & $\begin{array}{l}-0.0253 \\
(0.2790)\end{array}$ \\
\hline Female & $\begin{array}{c}-0.0093 \\
(0.0309)\end{array}$ & & & $\begin{array}{c}0.1633^{* * *} \\
(0.0429)\end{array}$ & $\begin{array}{r}-0.2475^{* * *} \\
(0.0407)\end{array}$ \\
\hline Married & $\begin{array}{c}0.0015 \\
(0.0243)\end{array}$ & $\begin{array}{c}-0.0671^{* * *} \\
(0.0245)\end{array}$ & $\begin{array}{c}0.3148^{* * *} \\
(0.0617)\end{array}$ & & \\
\hline Start Age & $\begin{array}{c}0.0013 \\
(0.0118)\end{array}$ & $\begin{array}{l}-0.0071 \\
(0.0129)\end{array}$ & $\begin{array}{c}0.0714^{* * *} \\
(0.0248)\end{array}$ & $\begin{array}{c}-0.0636^{* * *} \\
(0.0153)\end{array}$ & $\begin{array}{c}0.0175 \\
(0.0123)\end{array}$ \\
\hline Start Age-Sq. & $\begin{array}{c}0.0005^{* * *} \\
(0.0001)\end{array}$ & $\begin{array}{c}0.0005^{* * *} \\
(0.0002)\end{array}$ & $\begin{array}{l}-0.0003 \\
(0.0003)\end{array}$ & $\begin{array}{c}0.0013^{* * *} \\
(0.0002)\end{array}$ & $\begin{array}{l}0.0002^{*} \\
(0.0001)\end{array}$ \\
\hline Individuals & 72575 & 59227 & 13348 & 44797 & 27778 \\
\hline Quits & 15641 & 12897 & 2744 & 9424 & 6217 \\
\hline Returns & 21393 & 16750 & 4643 & 11568 & 9825 \\
\hline Observations & 1667335 & 1387393 & 279942 & 1125742 & 541593 \\
\hline Chi-Sq. ${ }^{\dagger}$ & $\begin{array}{c}101.57 \\
{[0.0000]}\end{array}$ & $\begin{array}{c}107.70 \\
{[0.0000]}\end{array}$ & $\begin{array}{c}36.14 \\
{[0.0000]}\end{array}$ & $\begin{array}{c}98.71 \\
{[0.0000]}\end{array}$ & $\begin{array}{c}40.48 \\
{[0.0000]}\end{array}$ \\
\hline Chi-Sq. ${ }^{\ddagger}$ & $\begin{array}{c}115.77 \\
{[0.0000]}\end{array}$ & $\begin{array}{c}122.23 \\
{[0.0000]}\end{array}$ & $\begin{array}{c}37.12 \\
{[0.0000]}\end{array}$ & $\begin{array}{c}108.36 \\
{[0.0000]}\end{array}$ & $\begin{array}{c}40.94 \\
{[0.0000]}\end{array}$ \\
\hline Quit Elasticity: & & & & & \\
\hline Unemp. Rate $=4$ & $\begin{array}{l}-1.3716 \\
(0.0293)\end{array}$ & $\begin{array}{l}-1.5090 \\
(0.0288)\end{array}$ & $\begin{array}{l}-0.8465 \\
(0.0695)\end{array}$ & $\begin{array}{l}-1.9941 \\
(0.0487)\end{array}$ & $\begin{array}{l}-0.4979 \\
(0.0611)\end{array}$ \\
\hline Unemp. Rate $=6$ & $\begin{array}{l}-0.6053 \\
(0.0211)\end{array}$ & $\begin{array}{l}-0.6406 \\
(0.0237)\end{array}$ & $\begin{array}{l}-0.3996 \\
(0.0365)\end{array}$ & $\begin{array}{l}-0.9266 \\
(0.0280)\end{array}$ & $\begin{array}{l}-0.1127 \\
(0.0320)\end{array}$ \\
\hline Unemp. Rate $=8$ & $\begin{array}{c}0.0295 \\
(0.0354)\end{array}$ & $\begin{array}{c}0.0815 \\
(0.0357)\end{array}$ & $\begin{array}{l}-0.0286 \\
(0.0751)\end{array}$ & $\begin{array}{l}-0.0900 \\
(0.0345)\end{array}$ & $\begin{array}{c}0.2935 \\
(0.0933)\end{array}$ \\
\hline Unemp. Rate $=10$ & $\begin{array}{c}0.5330 \\
(0.0264)\end{array}$ & $\begin{array}{c}0.6572 \\
(0.0275)\end{array}$ & $\begin{array}{c}0.2663 \\
(0.0436)\end{array}$ & $\begin{array}{c}0.5158 \\
(0.0281)\end{array}$ & $\begin{array}{c}0.7204 \\
(0.0740)\end{array}$ \\
\hline
\end{tabular}

${ }^{a}$ Included fixed effects: Firm, Month and Year.

b Standard errors clustered on the state are presented in parentheses. P-values are in brackets.

$\mathrm{c} * 0.10, * * 0.05$ and $* * * 0.01$ denote significance levels.

$\dagger$ Chi squared statistic for the joint test of cyclicality (two interactions terms equal zero: $\ln ($ Salary) $\times$ UR and $\ln$ (Salary) $\times$ UR-squared).

$\ddagger$ Chi squared statistic for the joint test of non-zero elasticities (three log salary terms equal zero: $\ln$ (Salary), $\ln ($ Salary $) \times$ UR and $\ln ($ Salary $) \times$ UR-squared $)$. 
Table 5: Competing Risk Regression Results: Return to India

\begin{tabular}{|c|c|c|c|c|c|}
\hline & 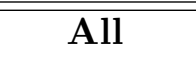 & Male & Female & Married & Single \\
\hline $\ln$ (Salary) & $\begin{array}{c}0.2937 \\
(0.5219)\end{array}$ & $\begin{array}{c}0.4621 \\
(0.5080)\end{array}$ & $\begin{array}{c}0.5101 \\
(1.2919)\end{array}$ & $\begin{array}{c}0.4496 \\
(0.5370)\end{array}$ & $\begin{array}{c}0.3147 \\
(1.0401)\end{array}$ \\
\hline $\ln ($ Salary $) \times$ UR & $\begin{array}{c}-0.4638^{* * *} \\
(0.1403)\end{array}$ & $\begin{array}{c}-0.5052^{* * *} \\
(0.1396)\end{array}$ & $\begin{array}{c}-0.5552^{*} \\
(0.3108)\end{array}$ & $\begin{array}{c}-0.5202^{* * *} \\
(0.1556)\end{array}$ & $\begin{array}{l}-0.4045 \\
(0.2577)\end{array}$ \\
\hline $\ln ($ Salary $) \times$ UR-Sq & $\begin{array}{c}0.0269^{* * *} \\
(0.0084)\end{array}$ & $\begin{array}{c}0.0285^{* * *} \\
(0.0089)\end{array}$ & $\begin{array}{c}0.0293^{*} \\
(0.0171)\end{array}$ & $\begin{array}{c}0.0296^{* * *} \\
(0.0102)\end{array}$ & $\begin{array}{c}0.0208 \\
(0.0140)\end{array}$ \\
\hline Unemp. Rate & $\begin{array}{c}5.2146^{* * *} \\
(1.5684)\end{array}$ & $\begin{array}{c}5.6578^{* * *} \\
(1.5652)\end{array}$ & $\begin{array}{l}6.3023^{*} \\
(3.4203)\end{array}$ & $\begin{array}{c}5.8264^{* * *} * \\
(1.7650)\end{array}$ & $\begin{array}{c}4.5786 \\
(2.8635)\end{array}$ \\
\hline Unemp. Rate-Sq. & $\begin{array}{c}-0.3024^{* * *} \\
(0.0946)\end{array}$ & $\begin{array}{c}-0.3185^{* * *} \\
(0.1007)\end{array}$ & $\begin{array}{c}-0.3345^{*} \\
(0.1882)\end{array}$ & $\begin{array}{c}-0.3306^{* * *} \\
(0.1156)\end{array}$ & $\begin{array}{l}-0.2367 \\
(0.1559)\end{array}$ \\
\hline Female & $\begin{array}{c}0.1979^{* * *} \\
(0.0400)\end{array}$ & & & $\begin{array}{c}0.0423 \\
(0.0504)\end{array}$ & $\begin{array}{c}0.3434^{* * *} \\
(0.0422)\end{array}$ \\
\hline Married & $\begin{array}{c}-0.4201^{* * *} \\
(0.0251)\end{array}$ & $\begin{array}{c}-0.4551^{* * *} \\
(0.0266)\end{array}$ & $\begin{array}{c}-0.4573^{* * *} \\
(0.0363)\end{array}$ & & \\
\hline Start Age & $\begin{array}{c}0.1460^{* * *} \\
(0.0299)\end{array}$ & $\begin{array}{c}0.2218^{* * *} \\
(0.0323)\end{array}$ & $\begin{array}{l}-0.0041 \\
(0.0334)\end{array}$ & $\begin{array}{c}0.1798^{* * *} \\
(0.0330)\end{array}$ & $\begin{array}{c}0.1829 * * * \\
(0.0366)\end{array}$ \\
\hline Start Age-Sq. & $\begin{array}{c}-0.0022^{* * *} \\
(0.0004)\end{array}$ & $\begin{array}{c}-0.0030^{* * *} \\
(0.0004)\end{array}$ & $\begin{array}{l}-0.0010^{*} \\
(0.0005)\end{array}$ & $\begin{array}{c}-0.0025^{* * *} \\
(0.0005)\end{array}$ & $\begin{array}{c}-0.0032^{* * *} \\
(0.0005)\end{array}$ \\
\hline Individuals & 72575 & 59227 & 13348 & 44797 & 27778 \\
\hline Returns & 21393 & 16750 & 4643 & 11568 & 9825 \\
\hline Quits & 15641 & 12897 & 2744 & 9424 & 6217 \\
\hline Observations & 1667335 & 1387393 & 279942 & 1125742 & 541593 \\
\hline Chi-Sq. $^{\dagger}$ & $\begin{array}{c}10.94 \\
{[0.0042]}\end{array}$ & $\begin{array}{c}17.32 \\
{[0.0002]}\end{array}$ & $\begin{array}{c}3.19 \\
{[0.2028]}\end{array}$ & $\begin{array}{c}17.55 \\
{[0.0002]}\end{array}$ & $\begin{array}{c}2.64 \\
{[0.2676]}\end{array}$ \\
\hline Chi-Sq ${ }^{\ddagger}$ & $\begin{array}{c}243.76 \\
{[0.0000]}\end{array}$ & $\begin{array}{c}356.01 \\
{[0.0000]}\end{array}$ & $\begin{array}{c}96.91 \\
{[0.0000]}\end{array}$ & $\begin{array}{c}277.71 \\
{[0.0000]}\end{array}$ & $\begin{array}{c}127.88 \\
{[0.0000]}\end{array}$ \\
\hline Return Elasticity: & & & & & \\
\hline Unemp. Rate $=4$ & $\begin{array}{c}-1.1313 \\
(0.0212)\end{array}$ & $\begin{array}{l}-1.1030 \\
(0.0189)\end{array}$ & $\begin{array}{l}-1.2428 \\
(0.1696)\end{array}$ & $\begin{array}{l}-1.1584 \\
(0.0200)\end{array}$ & $\begin{array}{c}-0.9702 \\
(0.0715)\end{array}$ \\
\hline Unemp. Rate $=6$ & $\begin{array}{l}-1.5210 \\
(0.0130)\end{array}$ & $\begin{array}{l}-1.5438 \\
(0.0104)\end{array}$ & $\begin{array}{l}-1.7681 \\
(0.0654)\end{array}$ & $\begin{array}{l}-1.6077 \\
(0.0154)\end{array}$ & $\begin{array}{l}-1.3627 \\
(0.0189)\end{array}$ \\
\hline Unemp. Rate $=8$ & $\begin{array}{l}-1.6955 \\
(0.0179)\end{array}$ & $\begin{array}{l}-1.7566 \\
(0.0111)\end{array}$ & $\begin{array}{l}-2.0595 \\
(0.0759)\end{array}$ & $\begin{array}{l}-1.8207 \\
(0.0166)\end{array}$ & $\begin{array}{l}-1.5888 \\
(0.0376)\end{array}$ \\
\hline Unemp. Rate $=10$ & $\begin{array}{c}-1.6549 \\
(0.0209)\end{array}$ & $\begin{array}{c}-1.7416 \\
(0.0106)\end{array}$ & $\begin{array}{l}-2.1167 \\
(0.1041)\end{array}$ & $\begin{array}{c}-1.7972 \\
(0.0129)\end{array}$ & $\begin{array}{c}-1.6482 \\
(0.0493)\end{array}$ \\
\hline
\end{tabular}

a Included fixed effects: Firm, Month and Year.

b Standard errors clustered on the state are presented in parentheses. P-values are in brackets.

$\mathrm{c} * 0.10, * * 0.05$ and $* * * 0.01$ denote significance levels.

$\dagger$ Chi squared statistic for the joint test of $2 y$ clicality (two interactions terms equal zero: $\ln ($ Salary) $\times$ UR and $\ln$ (Salary) $\times$ UR-squared).

$\ddagger$ Chi squared statistic for the joint test of non-zero elasticities (three log salary terms equal zero: $\ln ($ Salary), $\ln ($ Salary $) \times$ UR and $\ln ($ Salary $) \times$ UR-squared $)$. 
Table 6: Oaxaca Decompositions by Gender and Marital Status

\begin{tabular}{lcc}
\hline \hline & Male-Female & Married-Single \\
\hline Group_1 & $11.1796^{* * *}$ & $11.2124^{* * *}$ \\
& $(0.0101)$ & $(0.0102)$ \\
Group_2 & $11.1052^{* * *}$ & $11.0909^{* * *}$ \\
& $(0.0105)$ & $(0.0095)$ \\
Difference & $0.0744^{* * *}$ & $0.1215^{* * *}$ \\
& $(0.0030)$ & $(0.0026)$ \\
Explained & $0.0372^{* * *}$ & $0.1030^{* * *}$ \\
& $(0.0030)$ & $(0.0030)$ \\
Unexplained & $0.0372^{* * *}$ & $0.0185^{* * *}$ \\
& $(0.0039)$ & $(0.0032)$ \\
\hline N & 72575 & 72575 \\
\hline Implied Monopsony: & & \\
Gap UR=4 & 0.1780 & 0.4715 \\
Gap UR=6 & 0.2346 & 1.2619 \\
\hline \hline
\end{tabular}

${ }^{\mathrm{a}}$ Included fixed effects: State, Firm, Month and Year.

b Included regressors: Unemp. Rate, Male, Married, Age, and Age-Sq.

c Standard errors clustered on the state are presented in parentheses.

$\mathrm{d} * 0.10, * * 0.05$ and $* * * 0.01$ denote significance levels.

e The implied monopsony gap is derived from equation ref\# in section ref\# by using the point estimates from Table ref\#. 
Table 7: Elasticity Estimates: Competing Risk Robustness Check

\begin{tabular}{lccccc}
\hline \hline & & \multicolumn{2}{c}{ Quit Elasticity } & \multicolumn{2}{c}{ Return Elasticity } \\
& & Cox PH & Comp. Risk & Cox PH & Comp. Risk \\
\hline & Spec 1 & -0.9362 & -0.0216 & -2.2667 & -1.6369 \\
& & $(0.1610)$ & $(0.1527)$ & $(0.1030)$ & $(0.0837)$ \\
No UR & Spec 2 & -1.5792 & -0.5331 & -2.5166 & -1.6176 \\
Interactions & Spec 3 & -1.5411 & -0.4677 & -2.7254 & -1.5067 \\
& & $(0.1181)$ & $(0.0870)$ & $(0.2274)$ & $(0.0926)$ \\
& \multirow{2}{*}{ Spec 4 } & -1.4862 & -0.3317 & -2.7926 & -1.5177 \\
& & $(0.1285)$ & $(0.0834)$ & $(0.2408)$ & $(0.0987)$ \\
& \multirow{2}{*}{ Spec 5 } & -1.5490 & & -2.8285 & \\
& & $(0.1268)$ & & $(0.2596)$ & \\
& \multirow{2}{*}{ Spec 1 } & -1.3799 & -0.4752 & -2.5693 & -1.8660 \\
& & $(0.0589)$ & $(0.0560)$ & $(0.0121)$ & $(0.0114)$ \\
UR =6 & Spec 2 & -1.8809 & -0.8801 & -2.6489 & -1.6850 \\
& & $(0.0491)$ & $(0.0432)$ & $(0.0149)$ & $(0.0113)$ \\
& \multirow{2}{*}{ Spec 3 } & -1.7141 & -0.7293 & -2.7463 & -1.4960 \\
& & $(0.0285)$ & $(0.0219)$ & $(0.0587)$ & $(0.0116)$ \\
& \multirow{2}{*}{ Spec 4 } & -1.6935 & -0.6053 & -2.8241 & -1.5210 \\
& & $(0.0333)$ & $(0.0211)$ & $(0.0688)$ & $(0.0130)$ \\
& \multirow{2}{*}{ Spec 5 } & -1.7340 & & -2.8463 & \\
& & $(0.0322)$ & & $(0.0798)$ & \\
\hline \hline
\end{tabular}

a The top panel of the table displays the estimates of the separation elasticities for different described specifications without interacting log salary with the unemployment rate or the unemployment rate squared. In the bottom panel of the table, the estimated separation elasticities are displayed for specifications that interact the unemployment rate and the unemployment rate squared with $\log$ salary. These results in the bottom panel of the table are displayed at an unemployment rate of 6-percent.

$\mathrm{b}$ In addition to the condition described in footnote $a$, specification 1 includes log salary, specification 2 adds controls for gender, marital status, start age and start age squared, specification 3 adds firm indicators, specification adds month and year indicators, and specification 5 adds state indicators.

c Standard errors clustered on the state are presented in parentheses.

$\mathrm{d} * 0.10, * * 0.05$ and ${ }^{* * *} 0.01$ denote significance levels. 
Figure 1: Distribution of Tenure

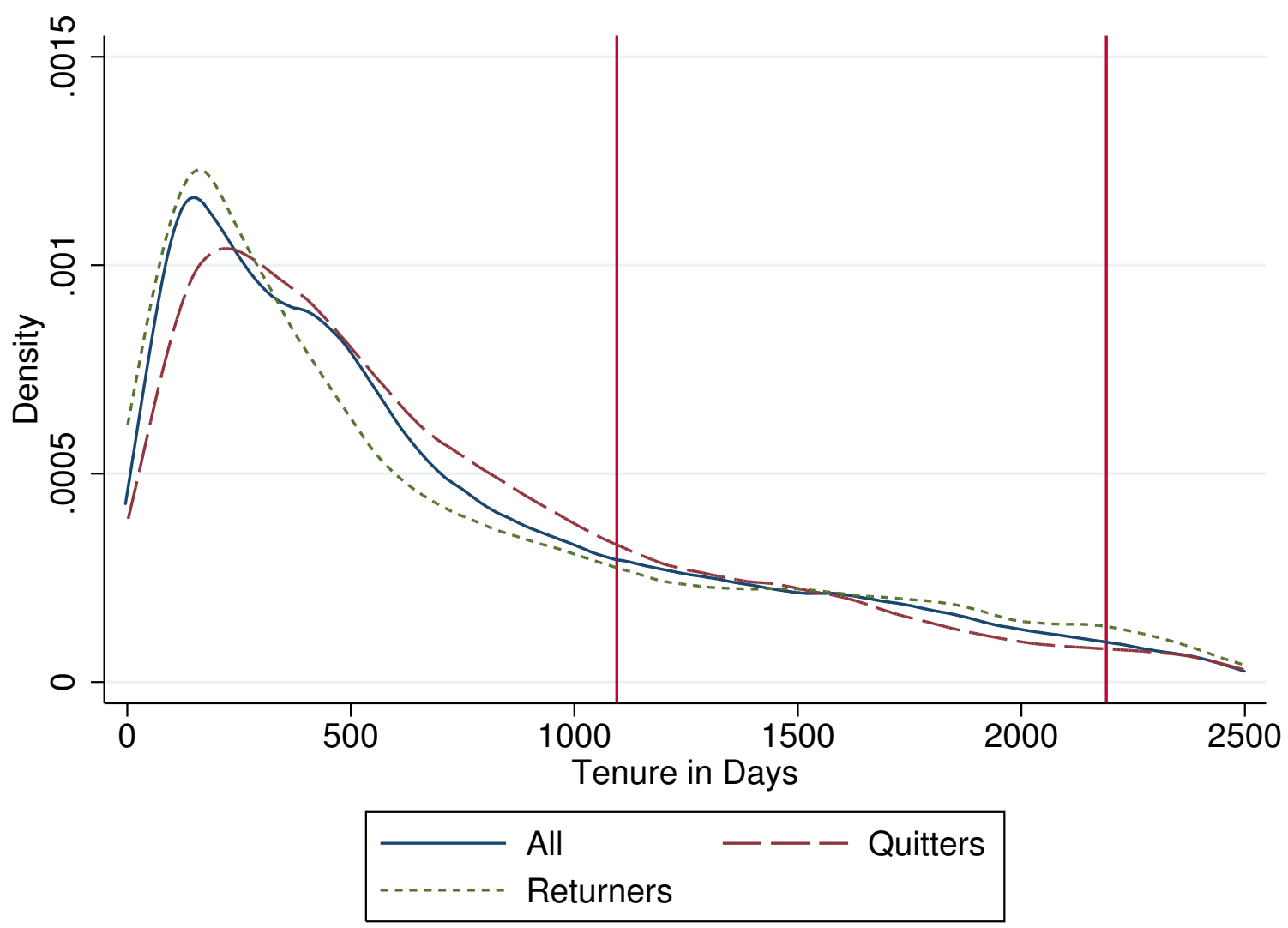


Figure 2: Quit and Return Rates

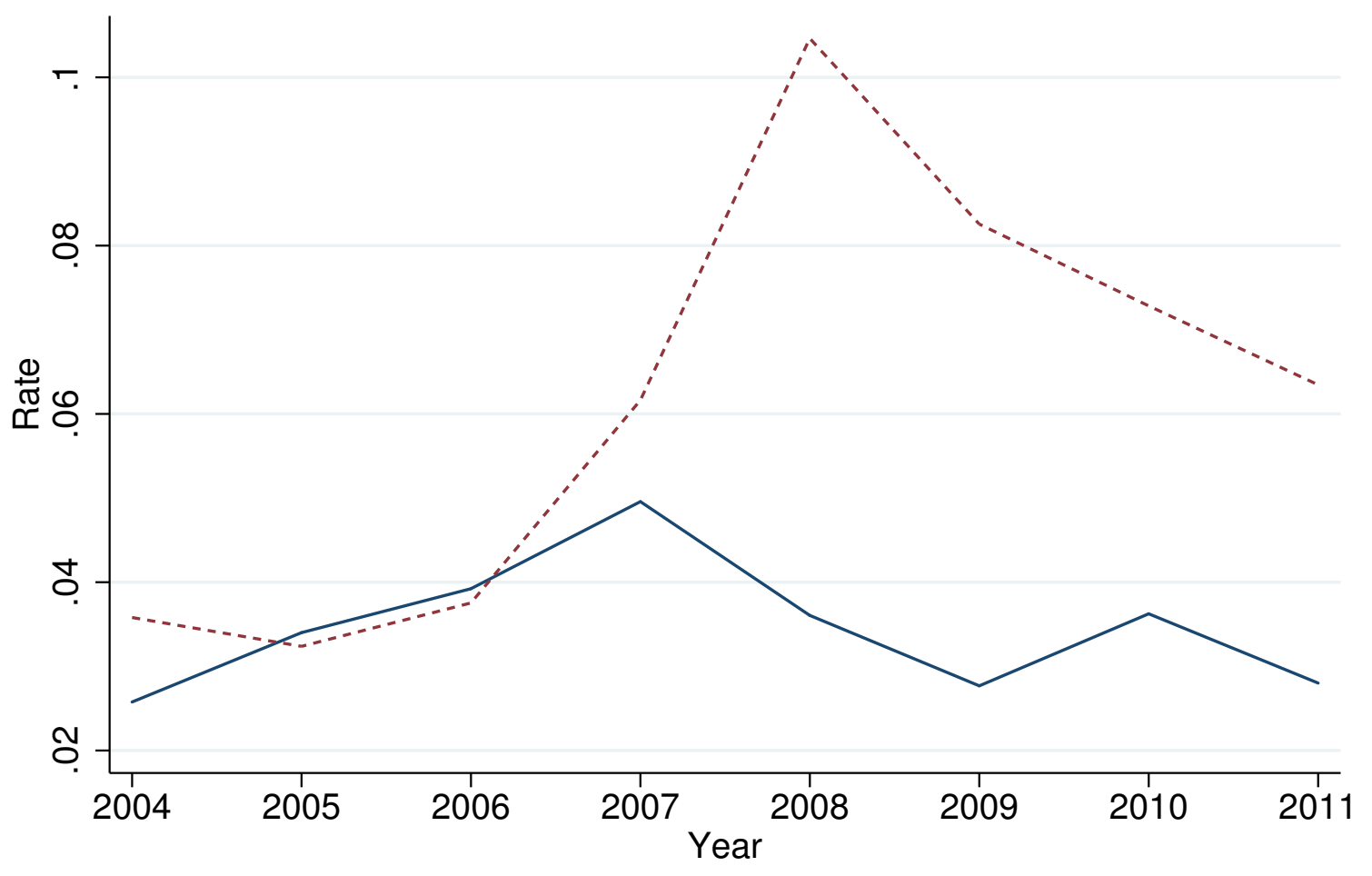

Quit Rate -...-. Return Rate 
Figure 3: Quit Elasticities for All Employees

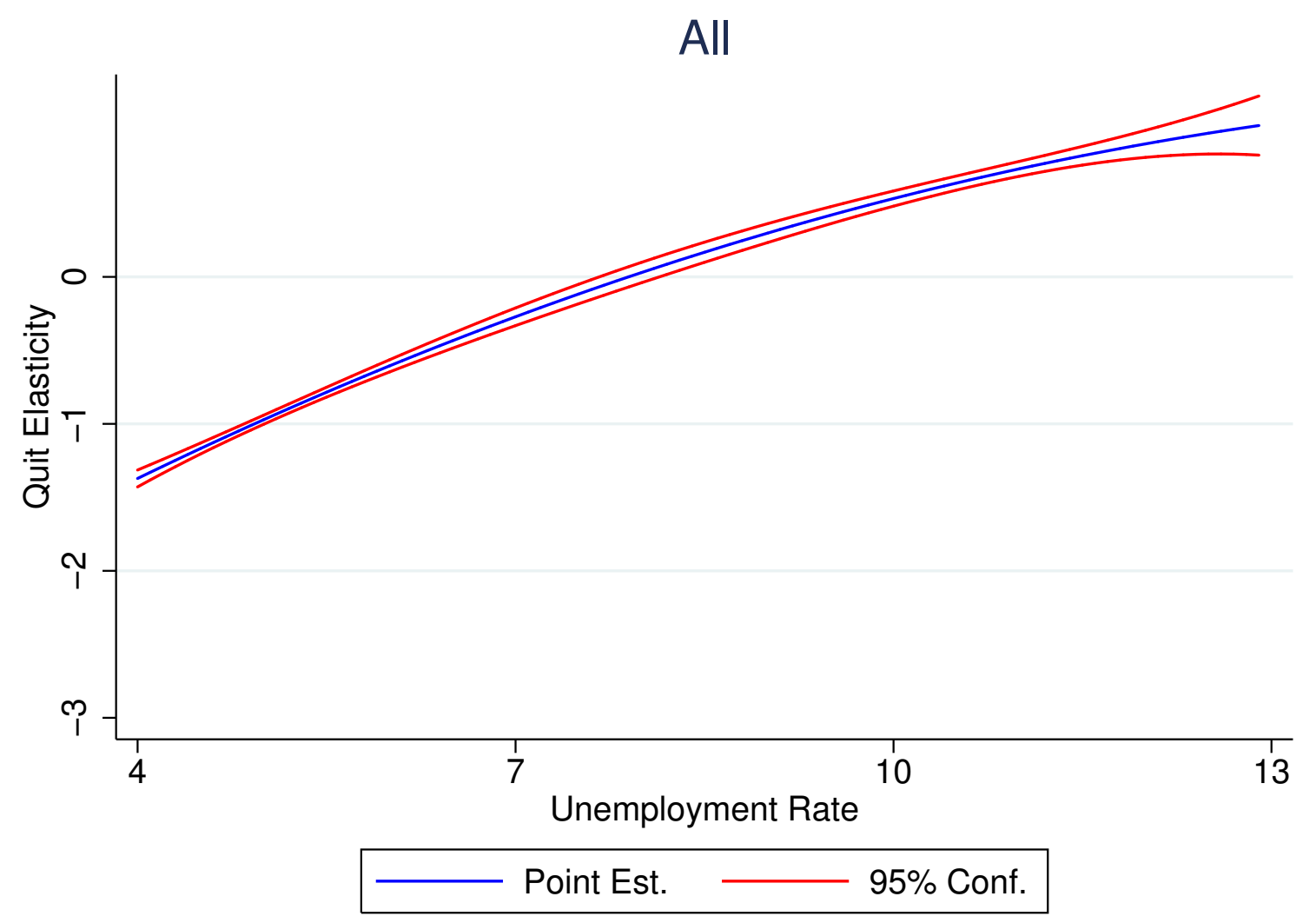


Figure 4: Quit Elasticities by Heterogenous Groups
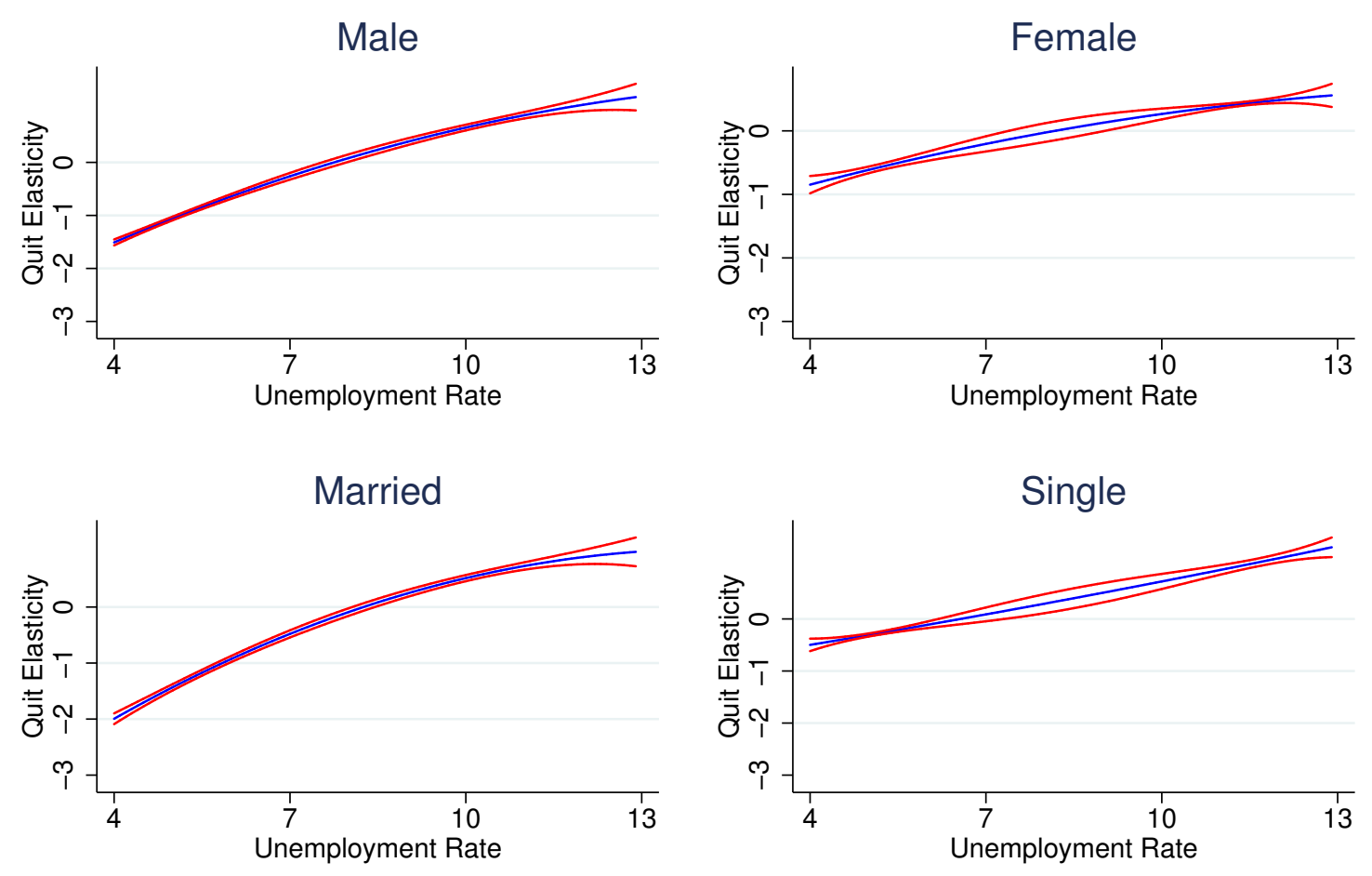

Point Est. 95\% Conf. 
Figure 5: Return Elasticities for All Employees

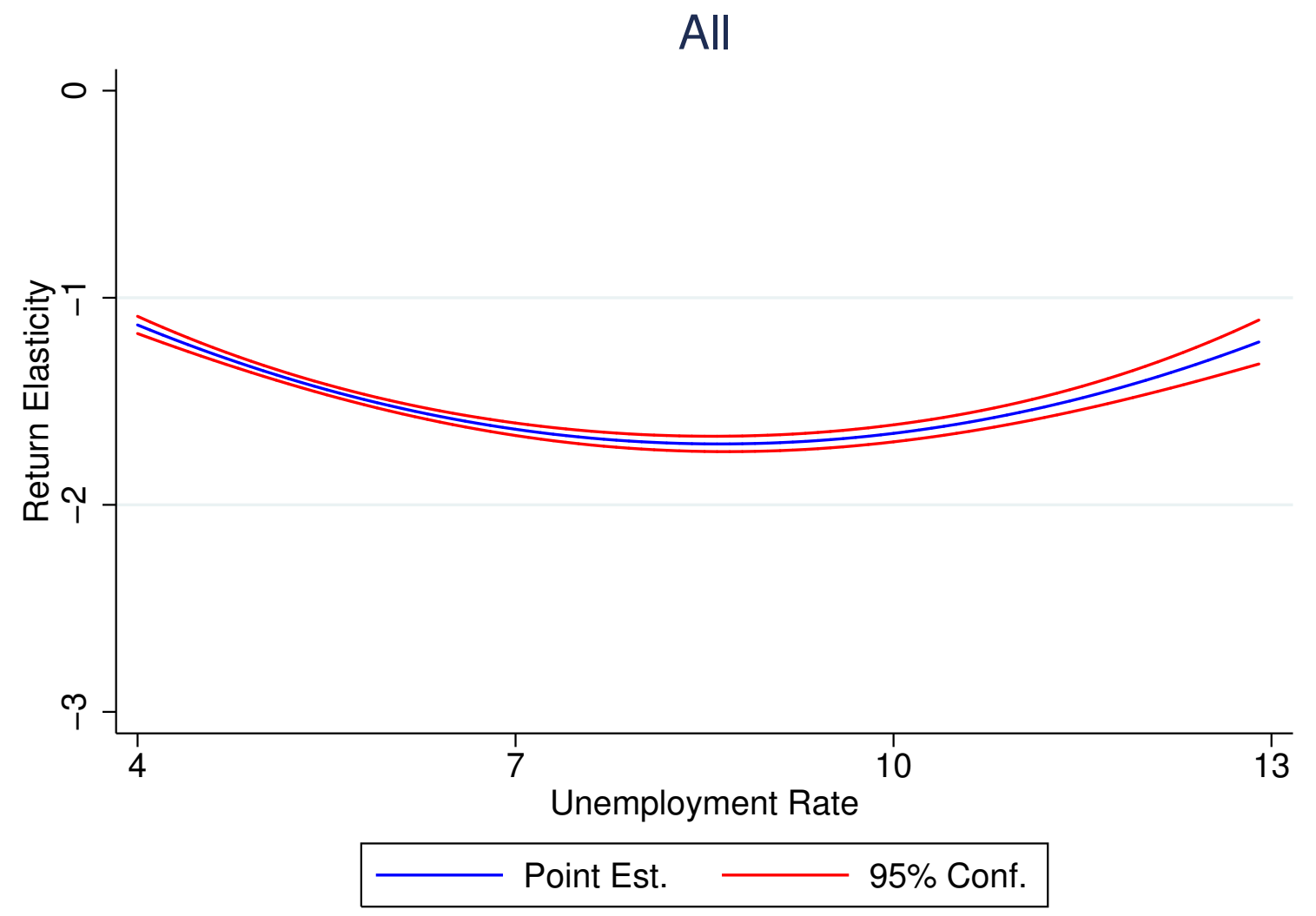


Figure 6: Return Elasticities by Heterogenous Groups
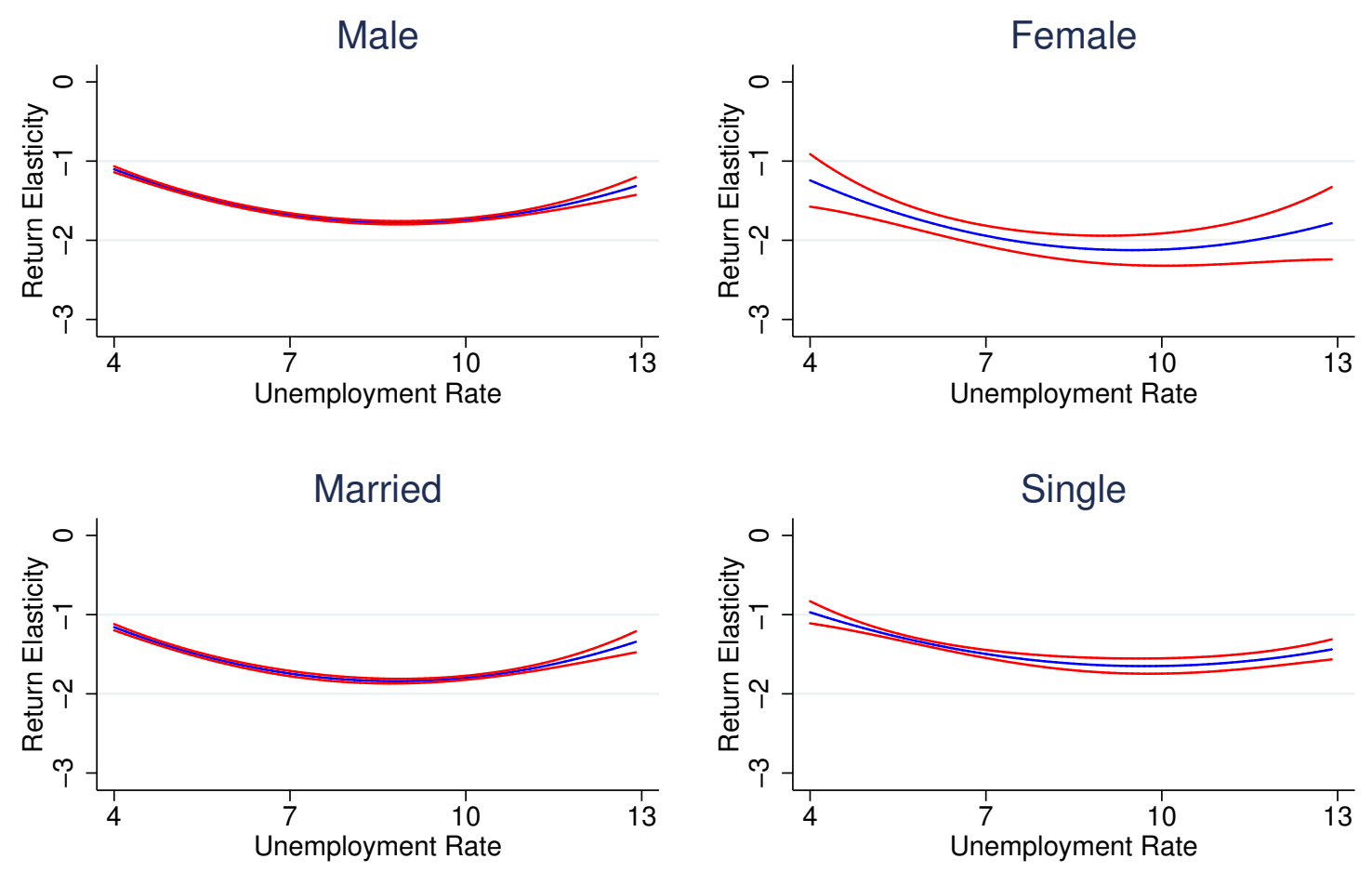

Point Est. $95 \%$ Conf. 
Figure 7: Previous Estimates of Elasticities

\section{Kernel density estimate}

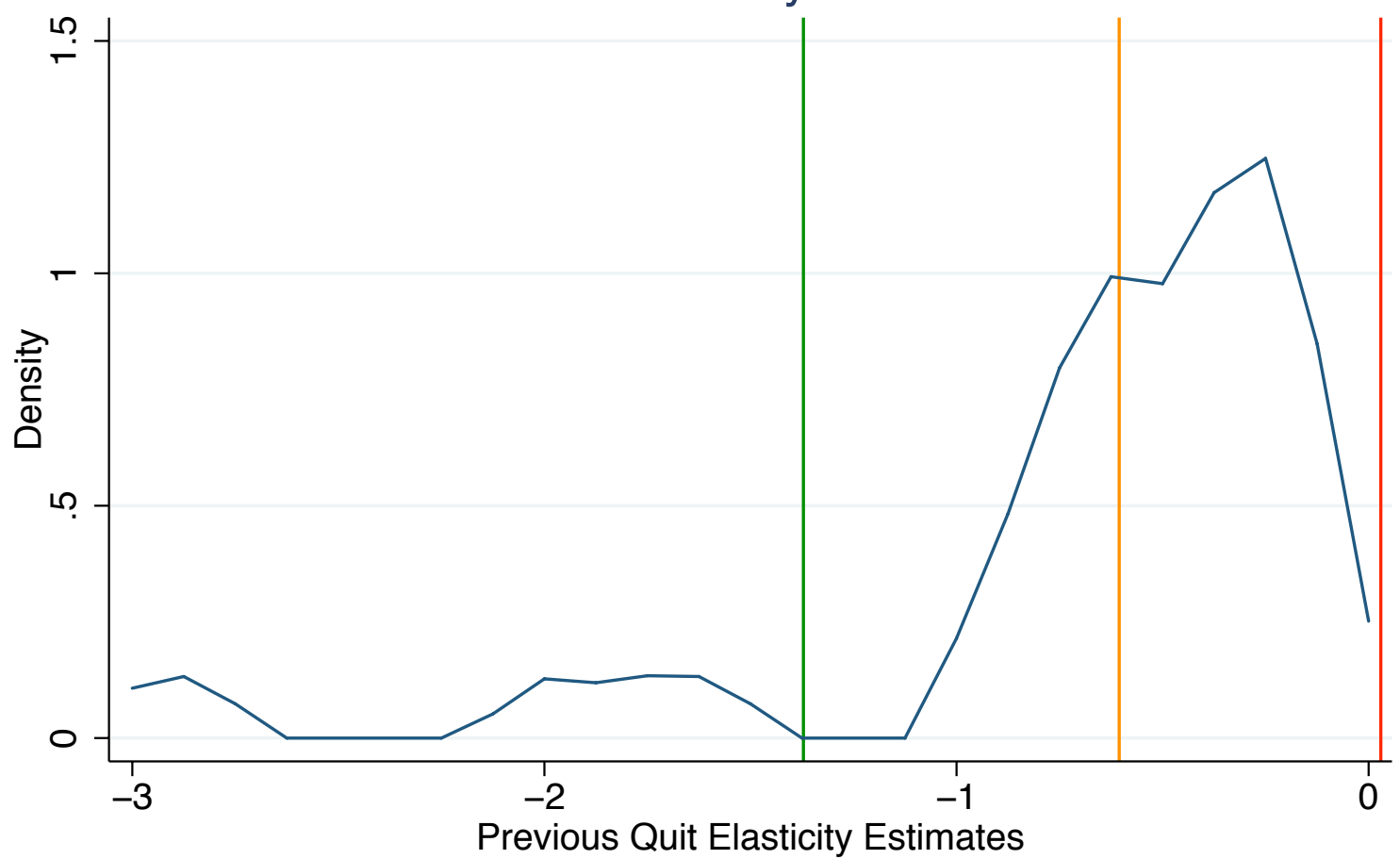

Note: The three vertical lines show the quit elasticities at different unemployment rates $(4 \%, 6 \%$ and $8 \%$ ). The green line is for a $U R=4$, the orange line is for a $U R=6$, and the red line is for a $U R=8$. 
Figure 8: Migration After the Great Recession
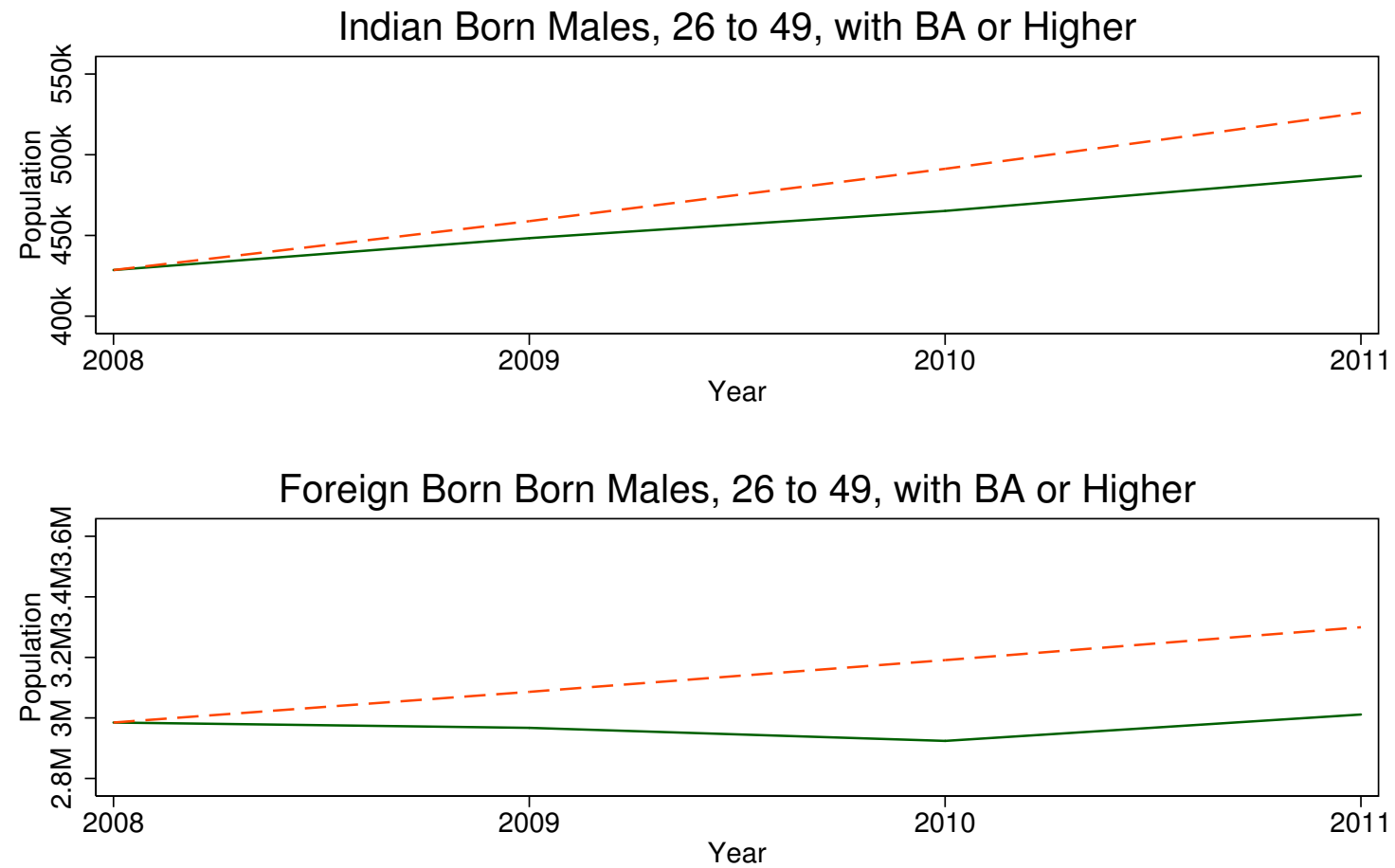

Actual - - - - Counterfactual (2000-2008 Trend Growth) 
Figure 9: EPOP with Discouraged Immigrants

\section{High Skilled Employment Population Ratio}

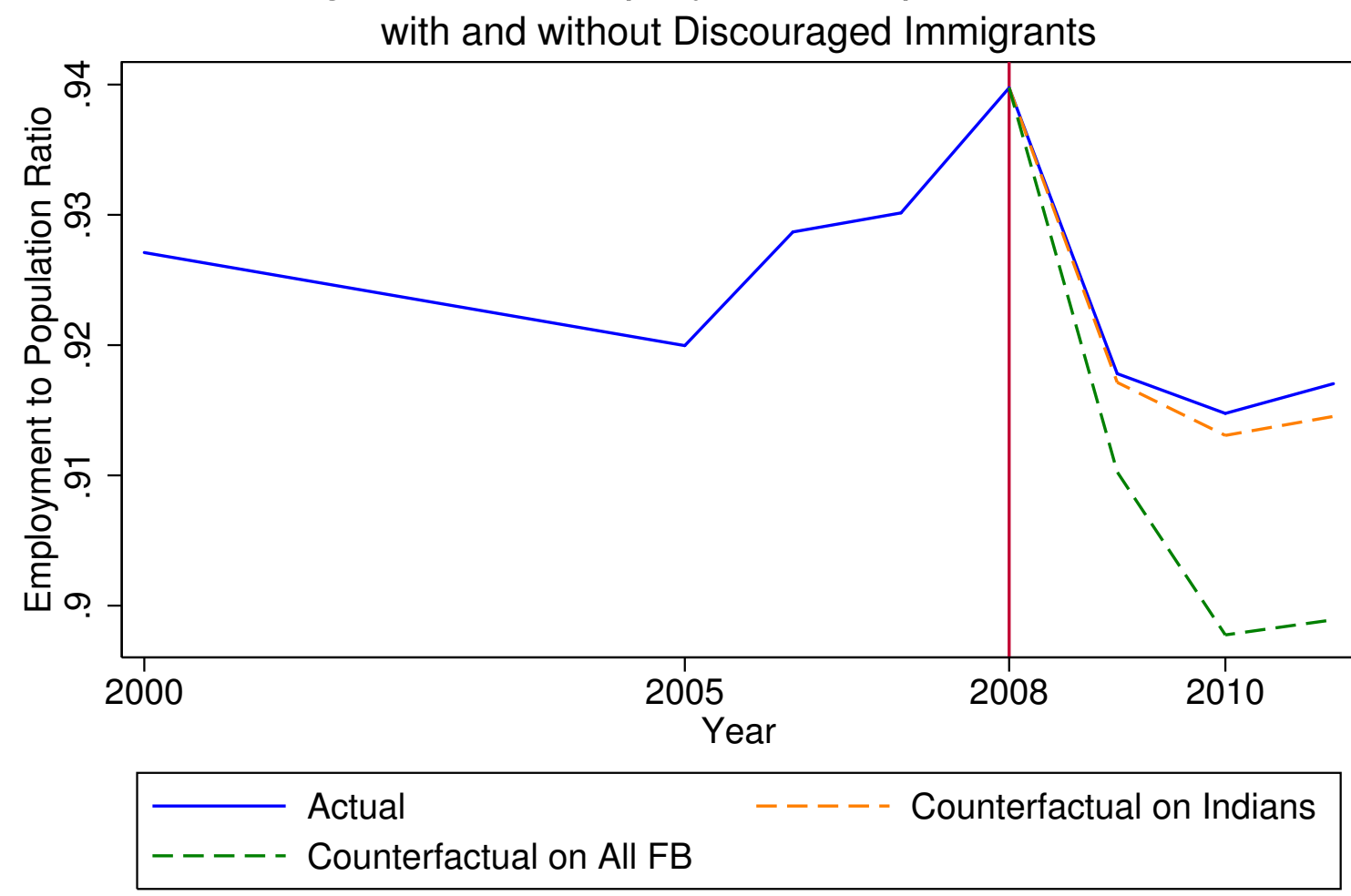




\section{A Wage Posting Model and Monopsonistic Com- petition}

Here we detail the relationship between search models and the quit elasticity. Manning bases his model on the Burdett and Mortensen (1998) search model. Their model of the separation rate is defined below

$$
s(w)=\delta+\lambda(1-F(w))
$$

The separation equation can be thought of in terms of both voluntary separations and involuntary separations. The term $\delta$ captures involuntary separations through exogenous job destruction. The second half of the equation gives the quit rate. Here, $\lambda$ is the job offer arrival rate, and $F(w)$ is the cumulative distribution of wage offers. Under this wage posting model, an individual separates from the firm when she receives an outside wage offer that dominates her current wage. The elasticity of quits with respect to the wage is then

$$
\epsilon_{q w}=\frac{\partial s}{\partial w} \frac{w}{s(w)}=\frac{-\lambda f(w)}{\delta+\lambda(1-F(w))} .
$$

This expression is finite if $\lambda$ is finite, meaning that there are search frictions which prevent workers from instantaneously and simultaneously receiving offers for all available jobs, and if $\mathrm{F}(\mathrm{w})$ is non-degenerate. The latter will happen if there are costs to filling vacancies, as these costs will generate an indeterminacy where there are many ways for firms to arrive at a zero profit condition. Firms may either take a "high road" where they pay a high wage and face a few recruiting costs, or firms can take a "low road" where they pay a low wage but have high turnover costs.

In the context of this labor market, we can conceptualize the effect of $\mathrm{H}-1 \mathrm{~B}$ visa costs as affecting workers by lowering $\lambda$. If it is costly to hire these workers then fewer firms may be willing to do so and thus fewer job offers will arrive to workers. It can be shown that the derivative of the elasticities with respect to $\lambda$ is negative. As $\lambda$ increases and frictions in the labor market decrease, workers will quit at higher rates in response to lower wages (Depew and Sorensen 2012). 


\section{Figure A1: Unexplained Pay Gap}
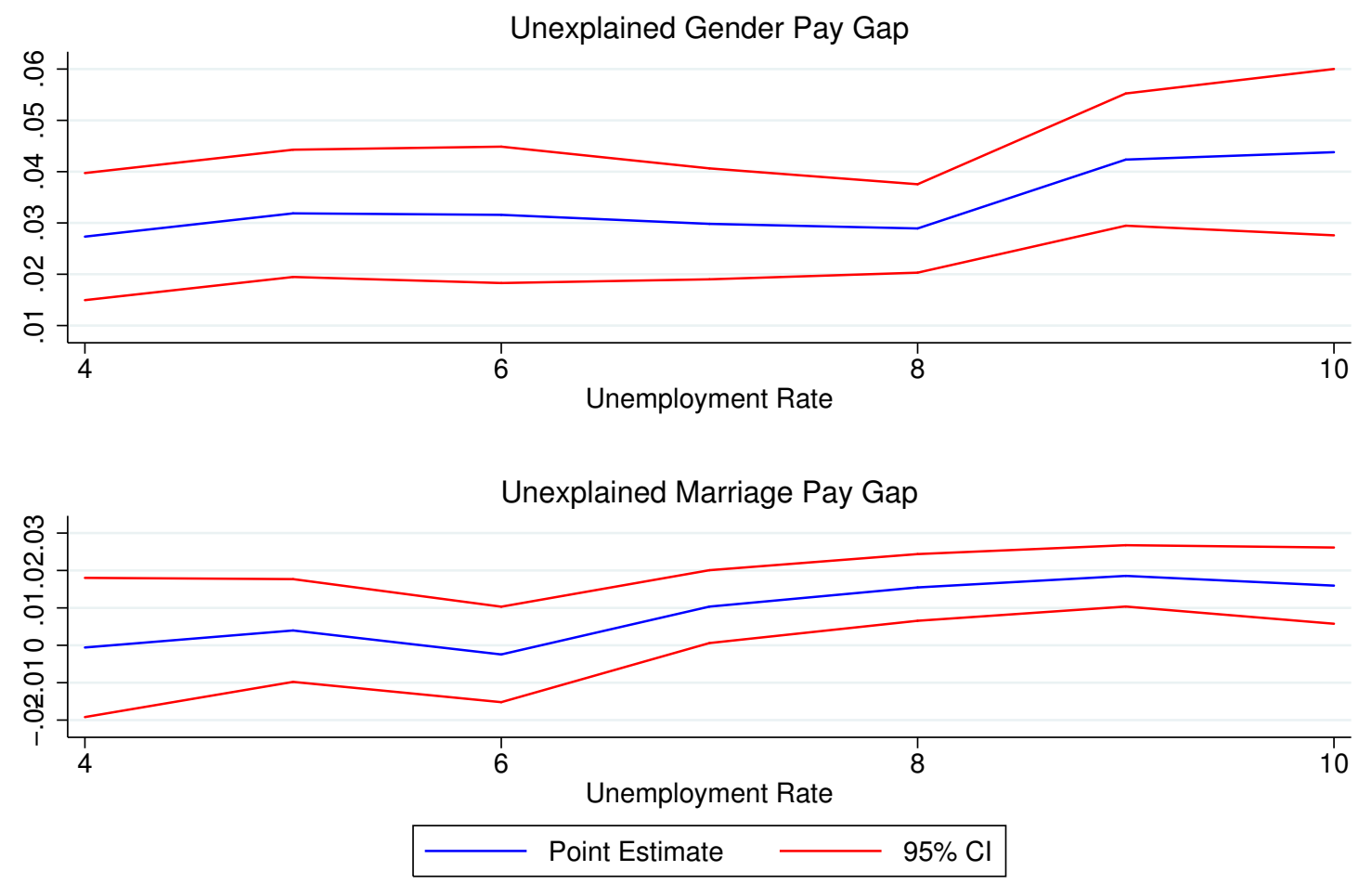

Note: The vertical axis displays the value of the unexplained difference from Oaxaca decompositions at unemployment rate bands of 3 percent. 